\title{
Phosphorylation of the v-erbA protein is required for its function as an oncogene
}

\author{
Corine Glineur, ${ }^{1}$ Martin Zenke, ${ }^{2}$ Hartmut Beug, ${ }^{2,3}$ and Jacques Ghysdael ${ }^{1}$ \\ ${ }^{1}$ Institut National de la Santé et de la Recherche Médicale U 186/Centre National de la Recherche Scientifique URA 1160, \\ Institut Pasteur, 59019 Lille Cedex, France; ${ }^{2}$ IMP, A 1030 Vienna, Austria
}

\begin{abstract}
The v-erbA oncogene of avian erythroblastosis virus (AEV) encodes a ligand-independent mutated version of the chicken c-erbAc-encoded thyroid hormone receptor. The v-erbA gene product, a $75-\mathrm{kD}$ gag/v-erbA fusion protein, is phosphorylated on Ser-16/17 of its v-erbA-encoded domain, and phosphorylation at this site is increased in vivo after activation of either the PKA or PKC signal transduction pathways. To test the hypothesis that phosphorylation of Ser-16/17 regulates gag/v-erbA protein function, mutant proteins in which Ser-16/17 had been changed to alanine or threonine residues were analyzed for their ability to inhibit erythroid differentiation of $t s \mathrm{v}$-erbB or $t s \mathrm{v}$-sea-transformed erythroblasts at nonpermissive temperature. Conversion of Ser-16/17 into alanine, although not affecting nuclear localization or DNA binding of the gag/erbA protein, prevented phosphorylation of the v-erbA-encoded domain of the protein both in unstimulated cells or after stimulation by PKA and PKC activators. The nonphosphorylatable AA-gag/v-erbA protein proved unable to inhibit temperature-induced differentiation of $t s \mathrm{v}$-erbB and $t s \mathrm{v}$-sea-transformed erythroblasts and to block expression of the erythrocyte-specific genes band 3 and carbonic anhydrase II. Back mutation of these alanine residues to serine resulted in the recovery of both normal phosphorylation levels and wild-type biological activity. In contrast, substitution of Ser-16/17 for threonine, which preserved phosphorylation in unstimulated cells but not PKA- and PKC-enhanced phosphorylation, resulted in a partially active gag/v-erbA protein. These results, together with the fact that the protein kinase inhibitor $\mathrm{H} 7$ resulted in both a dose-dependent inhibition of $g a g / v$-erbA protein phosphorylation and the induction of terminal differentiation of AEV-transformed erythroblasts show that phosphorylation of $\mathrm{gag} / \mathrm{v}$-erbA protein is required for full biological activity. These results support the hypothesis that phosphorylation of the $\mathrm{gag} / \mathrm{v}$-erbA protein is important for transcriptional repression of at least some of its target genes in erythroid cells.
\end{abstract}

[Key Words: v-erbA; oncogene; phosphorylation; erythroid differentiation]

Received May 28, 1990; revised version accepted August 2, 1990.

The mechanisms by which environmental factors essential to development and differentiation mediate transcriptional changes in the nucleus are still largely unknown. Binding of polypeptide hormones and growth factors to their plasma membrane receptor generates specific intracellular signaling events which, in turn, control the expression and/or activity of specific transcription factors /Greenberg and Ziff 1984; Sen and Baltimore 1986; Chiu et al. 1987; Montminy and Bilezikjian 1987; Lamph et al. 1988). On the other hand, a variety of hormones that exert profound effects on metabolic homeostasis, development, and differentiation (i.e., steroids, thyroid hormones, and retinoids) act through direct binding to specific nuclear receptors that are ligand-dependent transcription factors (for review, see Evans 1988).

The cellular progenitor $(c-e r b A \alpha)$ of $v$-erbA, one of the oncogenes of avian erythroblastosis virus (AEV), encodes a nuclear receptor for the thyroid hormone 3,5,3' -triiodothyronine $\left(\mathrm{T}_{3}\right)$ (Sap et al. 1986). Upon hormone

${ }^{3}$ Corresponding author. binding, this receptor enhances transcription of specific genes by associating selectively with DNA sequences termed thyroid hormone-responsive elements $\left(T_{3} R E\right.$; Damm et al. 1989; Sap et al. 1989). The c-erbA $\alpha$-encoded $\mathrm{T}_{3}$ receptor shares a similar modular structure with receptors for steroid hormones and retinoids/Green and Chambon 1986; Weinberger et al. 1985, 1986; Sap et al. 1986; de The et al. 1987; Giguere et al. 1987; Petkovich et al. 1987). All members of this family contain a highly conserved central domain containing two zinc finger motifs responsible for specific binding to hormone-responsive elements. The DNA-binding domain is separated by a hinge region from a carboxy-terminal domain that is responsible for hormone binding. The function of the amino-terminal domain of the c-erbA $\alpha$-encoded $T_{3}$ receptor has yet to be established.

The v-erbA gene product, a $75-\mathrm{kD} g a g / \mathrm{v}-e r b \mathrm{~A}$ fusion protein, binds to $\mathrm{T}_{3}$ REs (Damm et al. 1989; Sap et al. 1989) but fails to bind hormone as the result of multiple mutations in its carboxy-terminal domain (Sap et al. 1986, Munoz et al. 1988). v-erbA has been shown to cooperate with $\mathrm{v}-e r b \mathrm{~B}$, the second oncogene of $\mathrm{AEV}$, to in- 
duce transformation of chick erythroblasts in tissue culture and to cause acute erythroleukemia in chicks (Beug et al. 1982b, 1985a; Samarut and Gazzolo 1982; Frykberg et al. 1983; Sealy et al. 1983; Fung et al. 1983). More specifically, v-erbB, as well as other oncogenes encoding protein tyrosine kinases, are sufficient to induce extensive proliferation of erythroid progenitor cells but are unable to completely block the ability of these cells to differentiate terminally into erythrocytes, thus yielding a significant amount of mature cells in the transformed cultures (Beug et al. 1985a,b).

Expression of gag/v-erbA in these cells results in complete inhibition of their differentiation at an immature stage similar to that of CFU-E progenitor cells (Beug et al. 1979, 1985a; Samarut and Gazzolo 1982; Kahn et al. $1986 \mathrm{~b}$. In addition, expression of the $g a g / \mathrm{v}-\mathrm{erbA}$ protein results in the suppression of transcription of certain erythrocyte-specific genes such as carbonic anhydrase II (CA II) and erythrocyte anion transporter (band 3) (Zenke et al. 1988). Two sets of experimental evidence suggest that $g a g / v-e r b A$ inhibits erythroid differentiation by acting as a constitutive dominant repressor of erythrocyte-specific gene transcription (or of regulators of these genes) that is normally regulated by $\mathrm{T}_{3}$ or by retinoic acid (RA), because RA receptors have recently been shown to bind to and trans-activate at least some model $\mathrm{T}_{3} \mathrm{REs}$ (Graupner et al. 1989; Umesono et al. 1988). First, a $g a g / \mathrm{c}$-erbA $\alpha$ protein arrests erythroid differentiation and inhibits erythrocyte gene transcription when overexpressed in erythroblasts in the absence of hormone but promotes maturation and permits erythrocyte gene transcription in the presence of T3 (Zenke et al. 1990). Second, the $g a g / v-e r b A$ protein can function as a constitutive dominant repressor of model T3-responsive reporter plasmids in transient transfection assays (Damm et al. 1989; Sap et al. 1989).

We reported previously that the c-erbA $\alpha$-encoded $\mathrm{T} 3$ receptor is phosphorylated in its amino-terminal domain at two distinct sites (Goldberg et al. 1988). One of these sites (Ser-12) is phosphorylated in cells by casein kinase II or a kinase with similar specificity /Glineur et al. 1989), whereas phosphorylation of the second site (Ser-28/29) is mediated by an as yet uncharacterized protein kinase. Only this second phosphorylation site has been retained in the oncogenic $g a g / v-e r b A$ protein (Ser-16/17 in v-erbA coordinates; Goldberg et al. 1988). Phosphorylation of both Ser-28/29 in the c-erbA $\alpha$-encoded T3 receptor and Ser-16/17 in the gag/v-erbA protein was found to be enhanced following treatment of cells with activators of either protein kinase $\mathrm{C}(\mathrm{PKC})$ or cAMP-dependent protein kinase $(\mathrm{PKA}$; Goldberg et al. 1988), suggesting a role for these phosphorylation events in c-erbA $\alpha$ and v-erbA protein function.

To study the functional significance of $g a g / v-e r b A$ protein phosphorylation in oncogenesis, we analyzed the biochemical and biological properties of $g a g / \mathrm{v}-e r b A$ proteins in which Ser-16 and Ser-17 have been altered by site-directed mutagenesis into either unphosphorylatable alanine residues or into threonine. These studies, together with the effects of a protein kinase inhibitor on both gag/v-erbA protein phosphorylation and differentiation of AEV-transformed erythroblasts show that phosphorylation of the gag/v-erbA protein on Ser-16/17 is required for the protein to exert its full biological activity. Therefore, our results suggest that the gag/v-erbA protein has to be phosphorylated to repress at least a subset of the genes normally regulated by $T_{3}$ and/or other hormones (e.g., RA) during erythroid differentiation.

\section{Results}

\section{Construction of $v$-erb $A$ phosphorylation mutants by} site-directed mutagenesis

To analyze the importance of phosphorylation of Ser-16/ 17 for the biological activity of the gag/v-erbA protein, the codons for both Ser-16 and Ser-17 (Fig. 1A) were replaced with codons for either alanine (AA) or threonine (TT) by oligonucleotide site-directed mutagenesis. We also prepared a revertant form of the $g a g / v-e r b A$ protein in which the codons for Ala-16/17 in the AAgag/v-erbA protein were converted back to serine codons $\left(\mathrm{SS}^{\star}{ }^{*}\right.$; Fig. 1B).

The altered $g a g / \mathrm{v}-e r b \mathrm{~A}$ proteins were introduced into retroviral vectors containing temperature-sensitive versions of either v-erbB or v-sea (Fig. 1C; Scotting et al. 1987; Knight et al. 1987; Zenke et al. 1988). Virus stocks were prepared by cotransfection of these constructs together with RAV-1 DNA in chicken embryo fibroblasts.

A

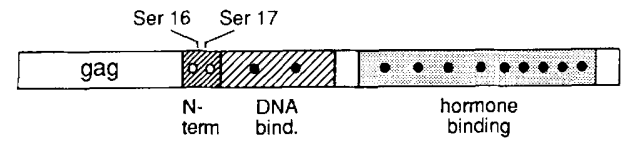

B gag-v-erbA Sequence

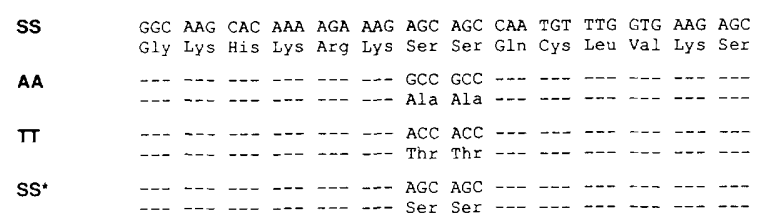

C

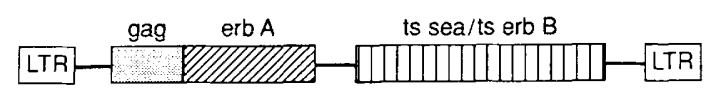

Figure 1. Structure of wild-type and mutant v-erbA proteins and recombinant retroviruses. $(A)$ Structure of the v-erbA oncogene, indicating the positions of the phosphorylated serine residues at positions 16 and $17(0)$. The amino-terminal, DNA-, and hormone-binding regions are indicated. (O) Point mutations. $(B)$ Nucleotide and amino acid sequences of the aminoterminal regions (nucleotides 28-69, corresponding to amino acids $10-23$ ) of the wild-type gag/v-erbA protein (SS), the mutant proteins alanine (AA) and threonine (TT) gag/v-erbA, and the serine $\left(\mathrm{SS}^{*}\right)$ gag/v-erbA back mutant, as constructed by site-directed mutagenesis (see Materials and methods). (C) Structure of the $t s \mathrm{v}$-erbB- or ts v-sea-containing retroviruses used to express wild-type and mutant v-erbA proteins in cells (Zenke et al. 1988). 
These vinuses, as well as vinuses containing a wild-type $\mathrm{v}$-erbA oncogene (ts 167 AEV and ts v-sea/v-erbA; Zenke et al. 1988) were used to generate transformed erythroblast clones from infected chicken bone marrow cells (see Materials and methods).

Both fibroblasts and erythroblasts transformed by viruses containing either wild-type or the various mutant $g a g / \mathrm{v}-e r b \mathrm{~A}$ oncogenes expressed comparable levels of the respective $g a g / \mathrm{v}$-erbA proteins, as evidenced by both immune precipitation of $\mathrm{L}-\left[{ }^{35} \mathrm{~S}\right]$ methionine pulse-labeled cells and by Western blotting analyses, using an erbAspecific antiserum (data not shown). In addition, both wild-type and AAgag/v-erbA proteins were found to be localized in the nucleus of transformed cells by immunofluorescence analysis (Fig. 2A) and were found to bind with similar efficiency to a synthetic palindromic $T_{3} R E$ oligonucleotide (Fig. 2B). Similar results were obtained for the TTgag/v-erbA protein (not shown). This indicates that substitution of Ser-16/17 for either alanine or threonine residues does not detectably alter the stability, subcellular localization, or DNA-binding ability of $g a g / \mathrm{v}-e r b \mathrm{~A}$ protein in transformed cells.

\section{In vivo phosphorylation of mutant $\mathrm{gag} / \mathrm{V}$-erb $A$ proteins}

We then analyzed the effect of the serine substitutions both on basal gag/v-erbA protein phosphorylation and on the enhanced phosphorylation observed following treatment of cells with either PKC activators or pharmacological agents that increase the intracellular concentration of cAMP. Transformed erythroblasts were labeled with $\left[{ }^{32} \mathrm{P}\right]$ orthophosphate for $4 \mathrm{hr}$ and either left untreated or further incubated for 20 min with either phorbol myristate acetate (PMA) or forskolin. The $g a g / v-e r b A$ proteins were immunoprecipitated with an erbA antiserum and analyzed by SDS-PAGE before or after proteolytic digestion with the p15 $5^{\text {gas }}$ protease of avian retroviruses. This protease cleaves the gag/v-erbA protein into a gag-encoded $30-\mathrm{kD}$ fragment (F30gag) and a $\mathrm{v}$-erbA-encoded $45-\mathrm{kD}$ fragment $\left(\mathrm{F} 45^{\mathrm{v}-e r b \mathrm{~A}}\right)$. Because Ser-16 and Ser-17 are the only residues phosphorylated in the v-erbA-encoded domain of the gag/v-erbA protein, this procedure allows a simple visualization of the phosphorylation status of these residues /Goldberg et al. 1988). As shown in Figure 2C, digestion of wild-type gag/v-erbA protein with p15ag generated both phosphorylated F30saz and F45 v-erbA fragments. The level of phosphate incorporation into F45 was enhanced $\sim 10$ fold upon pulse treatment of labeled cells for $20 \mathrm{~min}$ with either forskolin or PMA (Fig. 2C). As demonstrated previously, the enhanced phosphorylation of F45v-erbA occurred exclusively at Ser-16/17 and therefore represents an increase in the population of gag/v-erbA proteins phosphorylated at these residues (Goldberg et al. 1988). Similar results were obtained for erythroblasts expressing the revertant $\mathrm{SS}^{*} \mathrm{gag} / \mathrm{v}-\mathrm{er} b \mathrm{~A}$ protein /data not shown). In contrast, conversion of Ser-16/17 into alanine residues completely abolished both basal and forskolinor PMA-enhanced phosphorylation of the gag/v-erbA protein in its $\mathrm{F} 45^{\mathrm{v}-\mathrm{erbA}}$ fragment while leaving that of the gag-encoded domain unaffected (Fig. 2C, AA). These results confirm our prior biochemical identification of the
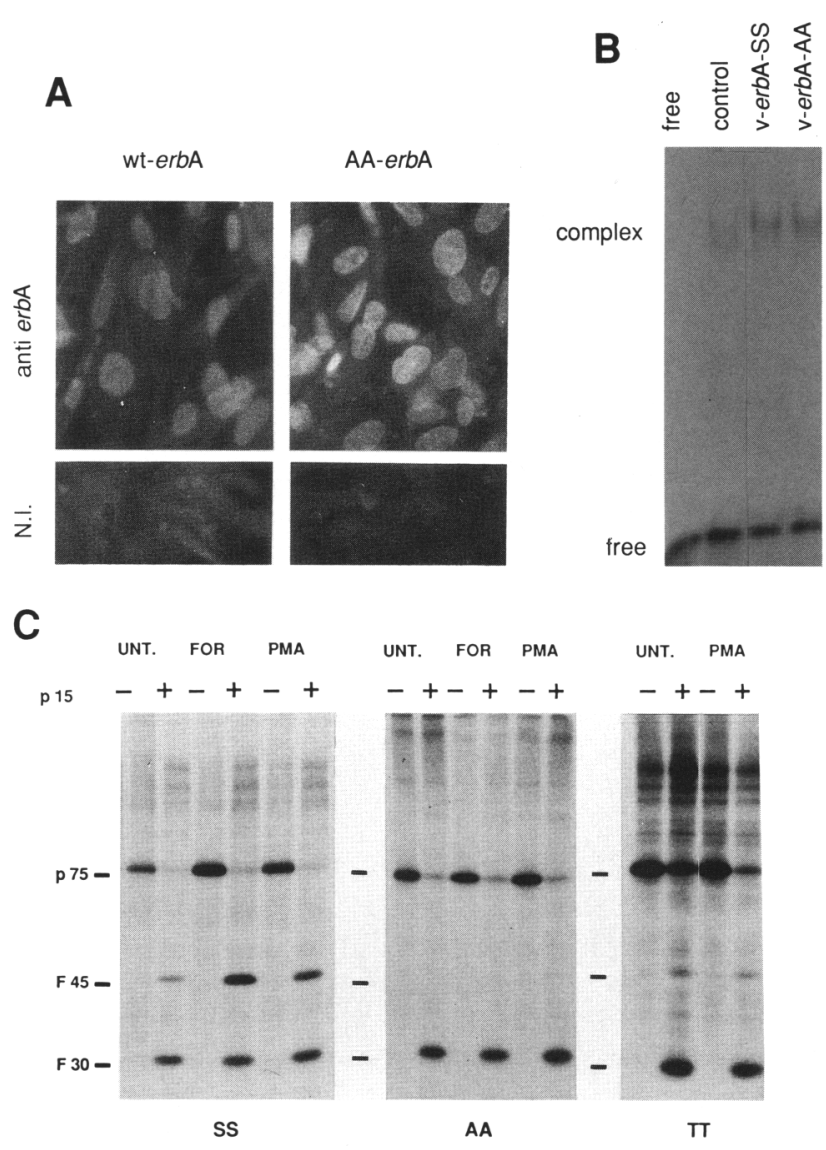

Figure 2. Properties of wild-type and mutant v-erbA proteins. (A) Immunofluorescence analyses. Fibroblasts transformed by either wild-type AEV (wt-erbA) or a mutant AEV encoding the AA-gag/v-erbA (AA-erbA) were grown on glass coverslips and fixed in paraformaldehyde, permeabilized, and stained with erbA-specific antiserum (anti-erbA) or nonimmune serum (N.I.) plus FITC swine anti-rabbit IgG antibodies, as described in $\mathrm{Ma}$ terials and methods. Note prominent nuclear fluorescence in both wt-erbA and AA-erbA cells. (B) Electrophoretic mobility shift assays. Mobility shift assays were performed, using a palindromic $T_{3} R E$ oligonucleotide (Glass et al. 1988) as probe, and either whole-cell extracts of COS cells transfected with the pKCR3 expression plasmid (control) or pKCR3-based plasmids expressing the wild-type $g a g / \mathrm{v}$-erbA protein (v-erbA-SS) or the mutant AA gag/v-erbA protein (v-erbA-AA). Free probe was electrophoresed in the first lane (free). The positions of free probe (free) and DNA-protein complex (complex) are indicated. (C) Phosphorylation of wild-type and mutant v-erbA proteins. Erythroblast cells containing either the wild-type gag/v-erbA protein (SS) or the mutant AA- and TT-gag/v-erbA proteins (AA) and (TT) were labeled for $4 \mathrm{hr}$ with $1 \mathrm{mCi} / \mathrm{ml}\left[{ }^{32} \mathrm{P}\right]$ orthophosphate. Cells were incubated further for $20 \mathrm{~min}$ with no agent (UNT.), $10 \mu \mathrm{M}$ forskolin (FOR), or $40 \mathrm{nM}$ PMA. Immunoprecipitation was carried out with an erbA-specific antiserum on equal aliquots of each lysate $\left(10^{7}\right.$ acid-precipitable radioactive counts per aliquot|. For each lysate, one of the two immunoprecipitates was digested with p15sag. Immunoprecipitates were analyzed by electrophoresis on $10 \%$ polyacrylamide slab gels. 
phosphorylation site of the wild-type gag/v-erbA protein of AEV as Ser-16/17 (Goldberg et al. 1988).

Conversion of Ser-16/17 into threonine residues resulted in phosphorylation of the gag/v-erbA protein in both the F30gag fragment on serine and the F45 ${ }^{\mathrm{v}-e r b \mathrm{~A}}$ fragment on threonine residues (Fig. 2C, TT, and data not shown). We reproducibly observed that the ratio of phosphate incorporation in $\mathrm{F}^{4} 5^{\mathrm{v}-\mathrm{erbA}}$ versus that of $\mathrm{F} 30^{\mathrm{g} a \mathrm{~g}}$ was lower in the TT gag/v-erbA protein than in the wild-type $g a g / v-e r b A$ protein. This suggests that this variant erbA protein is a less efficient substrate for the protein kinase(s) involved in the phosphorylation of the wild-type protein in erythroblasts. In striking contrast to wild-type $\mathrm{gag} / \mathrm{v}$-erbA protein, however, treatment of erythroblasts and fibroblasts expressing TT gag/v-erbA with either forskolin or PMA failed to result in enhanced phosphorylation of the F45 ${ }^{\mathrm{v}-\mathrm{erbA}}$ fragment (Fig. 2C, TT, and data not shown).

\section{Biological activity of mutant $\mathrm{gag} / \mathrm{V}$-erb $A$ proteins}

The rationale for testing the effects of the serine substitutions on the biological activity of $g a g / \mathrm{v}$-erbA proteins in erythroblasts was to combine them with a conditional transforming oncogene (e.g., temperature-sensitive mutants of v-erbB and v-sea; Fig. 1C). Previous analyses have shown that $t s \mathrm{v}$-erbB- or $t s \mathrm{v}$-sea-transformed erythroblast clones grown at the permissive temperature $\left(37^{\circ} \mathrm{C}\right)$ differentiated terminally into erythrocyte-like cells after "switching off" the temperature-sensitive kinase oncogene at the nonpermissive temperature $\left(42^{\circ} \mathrm{C}\right)$. In contrast, expression of the wild-type gag/v-erbA protein in these cells resulted in a dominant inhibition of differentiation, as evidenced by cell morphology, cellsurface antigen expression, and transcription of erythrocyte-specific genes (Kahn et al. 1986a,b; Zenke et al. 1988).

Differentiation phenotype As an initial screen for possible alterations in biological activity, a series of erythroblast clones expressing the SS-, AA-, and TT-gag/verbA proteins were tested for hemoglobin expression by acid benzidine staining after cultivation at 37 and $42^{\circ} \mathrm{C}$ for two days (Graf et al. 1978; Damm et al. 1987). As a negative control, erythroblast clones transformed by $t s$ $\mathrm{v}$-sea were used in this assay (no erbA in Fig. 3). Whereas the SS gag/v-erbA-expressing clones and, to a lesser extent, the TT-gag/v-erbA clones, exhibited the expected low hemoglobinization at $37^{\circ} \mathrm{C}$ and often contained $<95 \%$ hemoglobin-positive cells even at $42^{\circ} \mathrm{C}$ (Fig. $3 \mathrm{~B}, \mathrm{D})$, the AA-gag/v-erbA-expressing erythroblast clones closely resembled erythroblasts without any active erbA protein by this assay (Fig. 3A,C). These results suggest that the AA-gag/v-erbA protein might be devoid of biological activity, whereas the TT-gag/v-erbA protein displays a (perhaps weaker) activity of a v-erbA oncoprotein.

To determine in more detail the phenotypes induced by the mutant $g a g / \mathrm{v}-e r b \mathrm{~A}$ proteins in differentiating erythroblasts, representative erythroblast clones (se-
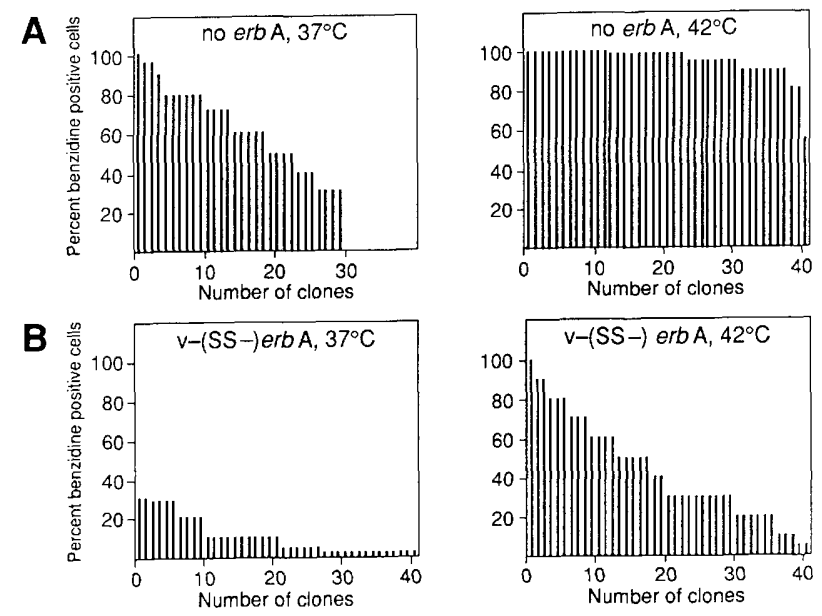

C
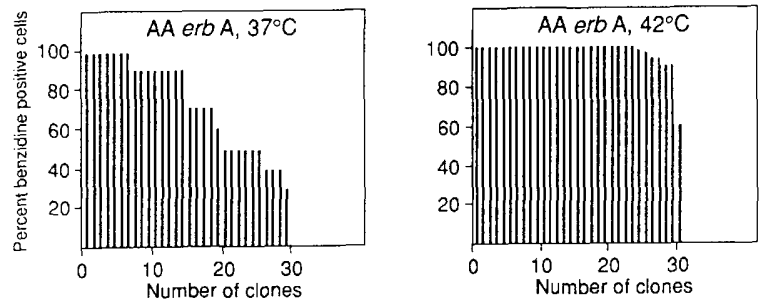

D
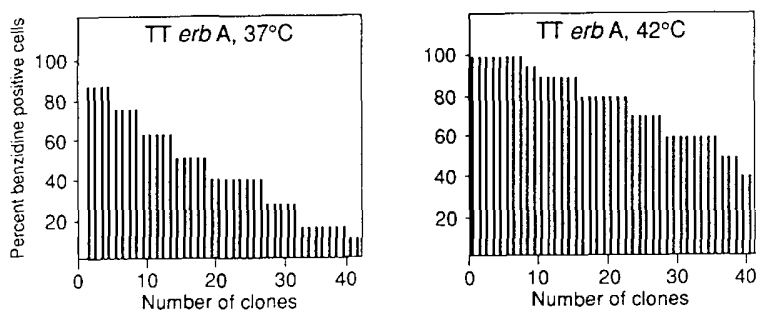

Figure 3. Hemoglobin expression in erythroblast clones expressing wild-type or mutant $\mathrm{v}$-erbA proteins. Individual erythroblast clones transformed by ts v-sea $(A$; no $e r b \mathrm{~A}), \mathrm{SS}$ gag/verbA/ts erbB (B, SS-erbA), AA gag/v-erbA/ts erbB (C, AA erbA), and TT gag/v-erbA/ts sea $(D$, TT erbA) were grown at 37 or $42^{\circ} \mathrm{C}$ for 2 days and analyzed for hemoglobin expression by acid benzidine staining (see Materials and methods). The histograms shown depict the clonal variation of acid benzidine staining within the various sets of clones. The data in $B$ are pooled from several experiments involving both $t s$ erbB/v-erbA and $t s$ sea/v-erbA retroviruses.

lected for high in vitro lifespan together with typical differentiation behavior; see Materials and methods) were cultivated at $42^{\circ} \mathrm{C}$ for 3 days and analyzed for other parameters of erythroid differentiation. The results indicate that the AA-gag/v-erbA was severely affected in its ability to arrest erythroid differentiation (Fig. 4; Table 1). Erythroblasts expressing this mutant protein formed CFU-E-like red colonies in semisolid medium (Fig. 4A). In mass culture, they differentiated into erythrocyte-like oval cells that were strongly hemoglobin-positive as evidenced by neutral benzidine staining (Fig. 4B) and expressed erythrocyte antigens at their cell surface (Table 1). Thus, these cells exhibited a phenotype very similar to that of $t s \mathrm{v}$-sea-transformed erythroblasts devoid of exogenous gag/v-erbA protein (Fig. 4A,B; Table 1).

The inability of the AA-gag/v-erbA protein to inhibit 


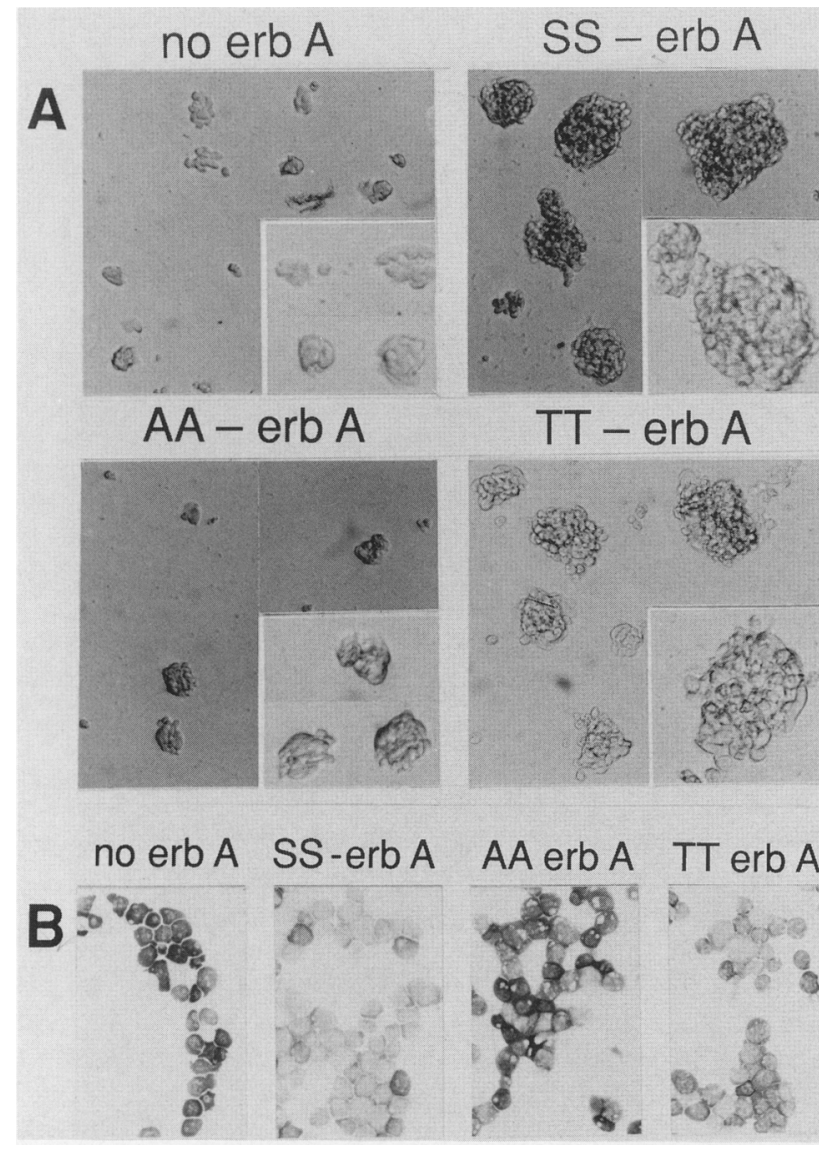

Figure 4. The nonphosphorylated AA-v-erbA mutant protein fails to arrest erythroid differentiation. Erythroblast clones transformed by retroviruses expressing wild-type or mutant erbA proteins (see legend to Table 1) were seeded in $\mathrm{pH} 7.2$ semisolid methocel medium (Zenke et al. 1988; see Materials and methods|. Photographs of typical colonies obtained after 3-4 days at $42^{\circ} \mathrm{C}$ are shown in $A$. (Insets) Some colonies at higher magnification reveal morphological details. $(B)$ Mass cultures of erythroblasts from the same clones as in $A$ were incubated in $\mathrm{pH} 7.2$ medium at $42{ }^{\circ} \mathrm{C}$ and $5 \% \mathrm{CO}_{2}$ for 3 days. Cytospin preparations of these cells were stained with neutral benzidine plus histological dyes (see Materials and methods) and were photographed under blue light to reveal histochemical staining for hemoglobin (Beug et al. 1982).

erythroid differentiation is directly attributable to the substitution of Ser-16/17 for alanine because a revertant $\mathrm{SS}^{*}$-gag/v-erbA protein was found to recover a biological activity indistinguishable from that of the wild-type SSgag/v-erbA protein (Table 1; data not shown).

In contrast, erythroblasts containing the TT-gag/verbA protein exhibited a clearly differentiation-arrested phenotype which, however, appeared to be less penetrant than the phenotype caused by either SS- or SS* $g a g / \mathrm{v}-e r b \mathrm{~A}$. The TT-gag/v-erbA erythroblasts formed pale, relatively large colonies in semisolid medium that seemed to consist of partially differentiated, sometimes oval cells (Fig. 4A), corresponding to the mixture of erythroblasts and early reticulocytes observed in mass cultures (Fig. 4B). These cells were found to express both immature and mature differentiation antigens (Table 1). Thus, the phenotype induced by TT-gag/v-erbA was similar to, but also distinct from, the typical, essentially immature phenotype displayed by both SS-gag/v-erbAand $\mathrm{SS}^{*}$-gag/v-erbA-expressing erythroblasts in these assays (Fig. 4; Table 1).

Medium requirements Besides causing a differentiation arrest, gag/v-erbA protein enables protein tyrosine kinase oncogene-transformed erythroblasts to proliferate in standard growth media, whereas erythroblasts devoid of a functional erbA protein require more complex growth conditions (CFU-E medium) mainly characterized by a narrow tolerance of $\mathrm{pH}, \mathrm{NaCl}$, and $\mathrm{NaHCO}_{3}$ concentrations (Kahn et al. 1986a,b; Damm et al. 1987). Accordingly, we compared the ability of erythroblasts expressing wild-type or mutant gag/v-erbA proteins to proliferate in these two media. Whereas erythroblasts expressing wild-type erbA proteins (SS-gag/v-erbA; SS*gag/v-erbA) grew in standard growth medium, cells containing the mutant proteins AA-gag/v-erbA or TT-gag/ $\mathrm{v}$-erbA did not, resembling ts v-sea erythroblasts in their medium requirements (Table 1). This inability to proliferate in standard medium was accompanied by development of large vacuoles in the AA- and TT-gag/v-erbAexpressing erythroblasts, eventually leading to cell disintegration. These results confirm that the TT-gag/v-erbA protein is only partially functional, perhaps corresponding to its weaker phosphorylation that cannot be enhanced by PKA or PKC activation.

Erythrocyte gene expression Because the AA-gag/verbA protein neither arrested erythroid differentiation nor altered the growth requirements of erythroblasts, it was of interest to analyze whether expression of this mutant protein is also accompanied by a loss in the ability to suppress erythrocyte-specific gene expression. Mass cultures of AA-gag/v-erbA-expressing erythroblasts were cultivated for 2 days at $42^{\circ} \mathrm{C}$, and aliquots were analyzed at either protein or RNA levels for the expression of band 3 and CA II. As controls, cultures of wild-type-gag/v-erbA (SS-gag/v-erbA)-expressing erythroblasts and $t s \mathrm{v}$-sea-transformed erythroblasts lacking erbA were treated similarly. Immunoprecipitation analyses of labeled lysates from these cells showed that expression of the AA-gag/v-erbA protein only reduced band 3 protein synthesis slightly, whereas expression of the SS-gag/v-erbA protein resulted in essentially complete suppression of band 3 protein levels under the same conditions (Fig. 5A). Similarly, expression of the CA II and band 3 RNAs was not or only partially reduced in AA-gag/v-erbA-expressing clones, whereas, as expected, their expression was almost completely abolished in erythroblasts transformed by the wild-type protein (Fig. 5B). These results suggest that the inability of the nonphosphorylated AA-gag/v-erbA mutant protein to block erythroid differentiation is mediated, at least in part, by its inability to completely shut down the expression of specific erythrocyte genes. 
Table 1. Differentiation phenotype and growth characteristics of wild-type and mutant erbA protein-expressing erythroblast clones

\begin{tabular}{|c|c|c|c|c|c|c|c|}
\hline \multirow[b]{2}{*}{ Construct ${ }^{\mathbf{a}}$} & \multicolumn{5}{|c|}{ Differentiation parameter ${ }^{b, c}$} & \multicolumn{2}{|c|}{ Growth $^{d}$} \\
\hline & $\begin{array}{c}\mathrm{LR}+\mathrm{E} \\
(\%)\end{array}$ & $\begin{array}{c}\text { ER } \\
(\%)\end{array}$ & $\begin{array}{l}\text { Ebl } \\
(\%)\end{array}$ & $\begin{array}{c}\text { anti- } \alpha \text { Ery } \\
(\%)\end{array}$ & $\begin{array}{c}\text { anti- } \alpha \mathrm{Ebl} \\
(\%)\end{array}$ & $\begin{array}{l}\text { doubling time } \\
\text { in EBM (hr) }\end{array}$ & $\begin{array}{c}\text { doubling time } \\
\text { in S13M (hr) }\end{array}$ \\
\hline no $e r b A$ & 88 & 10 & 2 & 93 & $>5$ & $>120$ & 20 \\
\hline $\mathrm{v}$ - $\{\mathrm{SS}\}$-erb $A$ & $5^{e}$ & 16 & 78 & 15 & 84 & 33 & 19 \\
\hline AA-erbA & 83 & 17 & 3 & 91 & 12 & $>120$ & 16 \\
\hline TT-erbA & $20^{\mathrm{e}}$ & 68 & 12 & 56 & 48 & $>120$ & 17 \\
\hline$S S^{*}-e r b A$ & $4^{e}$ & 13 & 83 & ND & ND & 22 & 15 \\
\hline
\end{tabular}

The following erythroblast clones were used: (no erbA) ts sea clone $\mathrm{H}_{2 ;}$ [v-(SS)-erbA] ts sea/v-erbA clone $\mathrm{F}_{1}$; (AA-erbA) ts erbB/AA erbA clone C8; (TT-erbA) ts sea/TTerbA clone B3; (SS*-erbA) ts sea/SS* erbA clone $\mathrm{E}_{1}$.

bPercentage of late reticulocytes (LR) plus erythrocytes (E), early reticulocytes (ER), and erythroblasts (Ebl) was determined by using cytospins stained with neutral benzidine plus histological dyes (Beug et al. 1982) after incubating the cells for 3 days at $42^{\circ} \mathrm{C}$ (see Materials and methods|.

'Percent cells distinctly positive with anti-erythrocyte serum $(\alpha$ Ery; Beug et al. 1979 ) or monoclonal antibody MC 4.5.A.5 ( $\alpha$ Ebl; Hayman et al. 1982). Cells were antibody-stained after incubation for 3 days at $42^{\circ} \mathrm{C}$. (ND) Not determined.

${ }^{\mathrm{d} C e l l s}$ were grown in standard growth medium (EBM) or CFU-E-medium (S13M) at $37^{\circ} \mathrm{C}$, as described in Materials and methods. Doubling times were calculated from semilogarithmic plots of cumulative cell number vs. time, using the time interval between 96 and $148 \mathrm{hr}$.

ePercentage of LR + E after 3 days at $42^{\circ} \mathrm{C}$ in pH 8.1 medium (Zenke et al. 1988) was $>95 \%$.

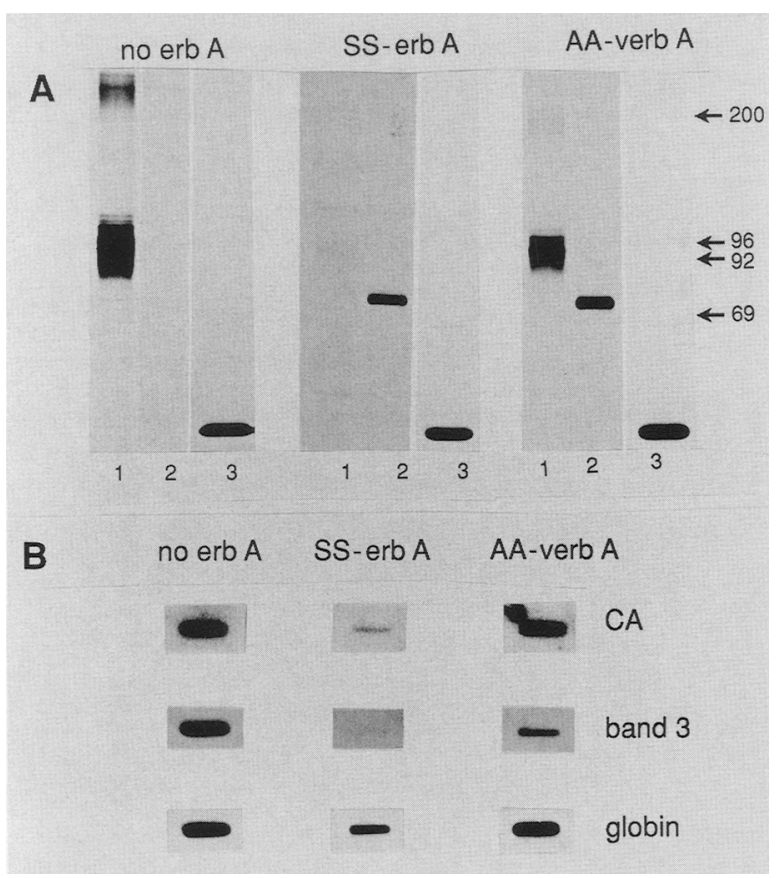

Figure 5. The AA gag/v-erbA protein is unable to suppress erythrocyte gene expression. (A) ts v-sea erythroblasts (clone $\mathrm{A} 4$; no $e r b \mathrm{~A}$ ), ts v-erbB/v-erbA erythroblasts (clone E3; SSerbA) and ts erbB/AA-erbA erythroblasts (clone C 8 ; AA-v-erbA) were grown at $42^{\circ} \mathrm{C}$ in $\mathrm{pH} 7.2$ medium for 3 days and labeled with $\left[{ }^{35} \mathrm{~S}\right]$ methionine, and extracts were immunoprecipitated with antibodies against band 3 protein (lanes 1), v-erbA (lanes 2), and globin (lanes 3; see Materials and methods; Zenke et al. 1988). The positions of molecular weight markers (right) are indicated by arrows. $(B)$ Cells from the same clones as in $A$ were cultivated at $42^{\circ} \mathrm{C}$ for 2 days and analyzed for expression of $\mathrm{CA}$ II-, band 3-, and globin-specific mRNA by slot-blot hybridization $15 \mathrm{mg}$ cytoplasmic RNA per slot, exposure times CA II, 16 $\mathrm{hr}$; band $3,16 \mathrm{hr}$; $\beta$-globin, $2 \mathrm{hr}$ ). It remains unclear whether the two- or threefold lower expression of band 3 RNA in the AAerbA erythroblasts is due to clonal variation or to a partial arrest of band 3 gene expression by the AA-erbA protein.
Inhibition of gag/v-erbA protein phosphorylation by the protein kinase inhibitor $H 7$ abolishes biological activity of the oncoprotein

The results described thus far demonstrate that integrity of the phosphorylation site of the gag/v-erbA oncogene protein is essential for its biological activity, suggesting an important role of phosphorylation in $g a g / \mathrm{v}$-erbA protein function. However, these experiments do not rule out the alternative possibility that mutation at Ser-16/ 17 leads to phosphorylation-independent conformational changes that impair protein function. If the former notion is correct, inhibition of $g a g / \mathrm{v}$-erbA protein phosphorylation by appropriate protein kinase inhibitors should result in a phenocopy of the AA-gag/verbA mutant.

$\mathrm{H} 7$ is one of several isoquinoline sulfonamide derivatives that act as direct inhibitors of several protein kinases at micromolar concentrations, including cyclic nucleotide-dependent protein kinases and PKC (Hidaka et al. 1984; Kawamoto et al. 1984). To analyze whether this inhibitor would affect growth and/or differentiation of cells lacking the v-erbA oncogene, the following experiments were performed. First, $t s$ v-erbB- or $t s \mathrm{v}-s e a-$ transformed erythroblasts were cultivated at either $37^{\circ} \mathrm{C}$ (for proliferation assays) or $42^{\circ} \mathrm{C}$ (to test differentiation) in the appropriate media (see Materials and methods) containing different amounts of $\mathrm{H} 7$. At concentrations of $10-15 \mu \mathrm{M}, \mathrm{H} 7$ had no detectable effects on the proliferation and spontaneous differentiation of these cells at $37^{\circ} \mathrm{C}$ [they grew with comparable doubling times $(18 \mathrm{vs}$. $19 \mathrm{hr}$ ), incorporated similar amounts of tritiated thymidine, and expressed similar proportions of partially and completely differentiated cells $(23.5 \mathrm{vs.} 21 \%)$ in the absence or presence of $\mathrm{H} 7$, respectively]. At $42^{\circ} \mathrm{C}, \mathrm{H} 7 \mathrm{did}$ not detectably affect temperature-sensitive maturation of $t s \mathrm{v}$-sea-transformed erythroblasts (Table 2). In addition, no reduction of proliferation rate or alterations in differentiation capacity were seen in myeloid cells in- 
Table 2. Abrogation of the v-erbA-induced arrest of erythroid differentiation by the protein kinase inhibitor $\mathrm{H7}$

\begin{tabular}{|c|c|c|c|c|c|}
\hline \multirow[b]{2}{*}{ Construct } & \multirow[b]{2}{*}{$\mathrm{H} 7^{\mathrm{a}}$} & \multicolumn{4}{|c|}{ Differentiation parameter } \\
\hline & & $\begin{array}{c}\mathrm{LR}+\mathrm{E} \\
(\%)\end{array}$ & $\begin{array}{c}\text { ER } \\
|\%|\end{array}$ & $\begin{array}{l}\mathrm{Ebl} \\
(\%)\end{array}$ & $\begin{array}{c}\text { anti-Ery3 } \\
\{\% \mid\end{array}$ \\
\hline \multirow{2}{*}{$\begin{array}{l}\text { no } \operatorname{erb} A \\
\quad(\text { ts sea/ts } \operatorname{erb} B)\end{array}$} & - & 90 & 10 & $<0.5$ & 90 \\
\hline & + & 88 & 11 & $<0.5$ & 95 \\
\hline \multirow[t]{2}{*}{ SS-erbA } & - & 10 & 41 & 49 & 19 \\
\hline & + & 78 & 20 & 2 & 80 \\
\hline \multirow[t]{2}{*}{ AA-erbA } & - & 78 & 16 & 2 & 85 \\
\hline & + & 80 & 15 & 1 & 85 \\
\hline
\end{tabular}

For abbreviations, see Table 1 footnote.

${ }^{a}$ The protein kinase inhibitor H7 (Seikagaku) was used at $15 \mu \mathrm{M}$ (see Materials and methods).

bifferentiation parameters (see Table 1) were determined after incubating the cells at $42^{\circ} \mathrm{C}$ for 3 days.

fected with an E26 virus temperature-sensitive mutant and grown at 37 or $42^{\circ} \mathrm{C}$ in the presence of $\left.15 \mu \mathrm{M} \mathrm{H}\right\rangle(\mathrm{H}$. Beug, unpubl.).

Higher concentrations $(25-100 \mu \mathrm{M})$ of $\mathrm{H} 7$ were increasingly toxic on erythroblast clones. Cells from the $t s$ 34 AEV-transformed cell-line HD3 (Beug et al. 1982a) when tested for proliferation at $37^{\circ} \mathrm{C}$ tolerated much higher doses of the drug, showing a significant growth inhibition only at 30-40 $\mathrm{MM}$ (data not shown).

The effects of $\mathrm{H} 7$ on gag/v-erbA protein phosphorylation were analyzed next. HD3 erythroblasts were incubated for 2 days in either $\mathrm{S} 13$ medium at $37^{\circ} \mathrm{C}$ or differentiation medium at $42^{\circ} \mathrm{C}$ in the continuous presence of $20 \mu \mathrm{M} \mathrm{H7}$. Thereafter, cells were labeled with [ $\left.{ }^{32} \mathrm{P}\right]$ orthophosphate for $3 \mathrm{hr}$ in the presence of $20 \mu \mathrm{M} \mathrm{H} 7$ and either were left untreated or were further treated for 20 min with forskolin or PMA before lysis and immune precipitation analyses. Treatment of AEV-transformed erythroblasts at either 37 or $42^{\circ} \mathrm{C}$ resulted in an almost complete inhibition of phosphorylation of the $g a g / v$ erbA protein in both its gag- and v-erbA encoded domains (Fig. 6; data not shown). This inhibition of phosphorylation was dose-dependent with a maximal inhibition occurring at $20 \mu \mathrm{M} \mathrm{H} 7$ for the HD3 cell line (data not shown). Similar results were obtained by using an erythroblast clone freshly transformed with a ts $\mathrm{v}$-erbB/ $\mathrm{v}$-erbA virus (ts $167 \mathrm{AEV})$ in the presence of $10 \mu \mathrm{M} \mathrm{H} 7$ (data not shown). In these experiments, $\mathrm{H} 7$ proved equally efficient at inhibiting both basal and forskolin-, or PMA-enhanced phosphorylation of the v-erbA-encoded domain of the $g a g / v-e r b A$ protein at all concentrations tested (Fig. 6). We therefore conclude that $\mathrm{H} 7$ effectively inhibits $g a g / v-e r b A$ phosphorylation at concentrations that have no detectable toxic effects on erythroblasts lacking a v-erbA oncogene.

The above results encouraged us to test whether $\mathrm{H} 7$ under the conditions described above would impair the biological activity of the gag/v-erbA protein. Erythroblasts expressing either wild-type SS-gag/v-erbA or mutant $e r b \mathrm{~A}$ protein (AA- and TT-gag/v-erbA) were cultivated at $42^{\circ} \mathrm{C}$ in the presence and absence of $10 \mu \mathrm{M} \mathrm{H} 7$ and analyzed for their differentiation phenotype and ex- pression of erythrocyte genes as described above. $\mathrm{H} 7$ was found to release the differentiation arrest in both SS- and TT-gag/v-erbA erythroblasts, as shown by the induction of red, compact colonies and reticulocyte/erythrocytelike cells strongly expressing hemoglobin and erythrocyte antigens (Fig. 7; Table 2). As expected, differentiation of erythroblasts expressing the nonphosphorylated AA-gag/v-erbA proteins was not grossly affected by $\mathrm{H} 7$ (Fig. 7; Table 2).

These results, suggesting that $\mathrm{H} 7$ strongly inhibits the biological activity of $\mathrm{v}$-erbA, were corroborated by the finding that the same inhibitor, to a large extent, was also able to relieve the repression of erythrocyte genes in transformed erythroblast clones expressing the $g a g / v-$ erbA protein. $\mathrm{H} 7$ was found to restore both $\mathrm{CA}$ II and band 3 mRNA expression in SS-gag/v-erbA-containing erythroblasts to levels only slightly lower than that in cells without v-erbA but did not affect the expression of control genes (e.g., globin, c-myb) in these cells (Fig. 8; data not shown). The H7-induced up-regulation of band 3 mRNA was matched by a proportional increase in band 3 protein synthesis (data not shown). Again, $\mathrm{H} 7 \mathrm{did}$ not grossly alter CA II and band 3 mRNA and protein expression in erythroblasts expressing either no erbA or the AA-gag/v-erbA protein (Fig. 8; data not shown). In conclusion, the results described here indicate that the arrest of both erythroid differentiation and erythrocyte

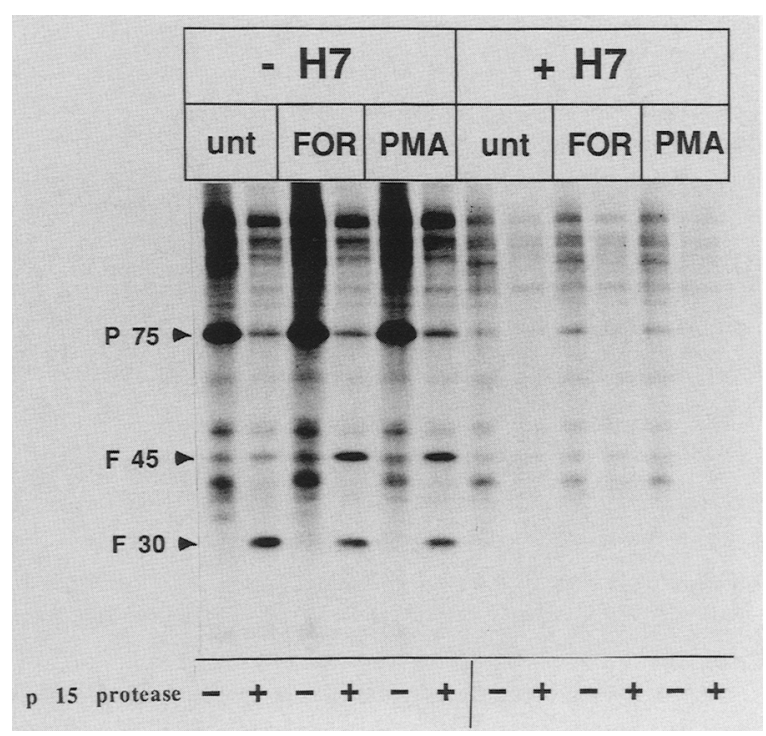

Figure 6. The protein kinase inhibitor $\mathrm{H} 7$ inhibits phosphorylation of v-erbA protein. Erythroblasts from the ts AEV-transformed cell line HD3 were cultivated for 2 days in the absence $(-\mathrm{H} 7)$ or the continuous presence of $20 \mu \mathrm{M} \mathrm{H} 7(+\mathrm{H} 7)$. Cells were labeled with $\left[{ }^{32} \mathrm{P}\right]$ orthophosphate for $3 \mathrm{hr}$ in the presence of $20 \mu \mathrm{M}$ of $\mathrm{H} 7(+\mathrm{H} 7)$ or in the absence of $\mathrm{H} 7(-\mathrm{H} 7)$ and were treated further for $20 \mathrm{~min}$ with no agent (unt), $10 \mu \mathrm{M}$ forskolin (FOR), or $40 \mathrm{nM}$ PMA. Immunoprecipitation was carried out with an erbA-specific antiserum on equal aliquots of each lysate $\left(10^{7}\right.$ acid-precipitable radioactive counts per aliquot). For each lysate, one of the two immunoprecipitates was digested with $\mathrm{p} 15^{\mathrm{gag}}$. Immunoprecipitates were analyzed by electrophoresis on $10 \%$ polyacrylamide slab gels. 


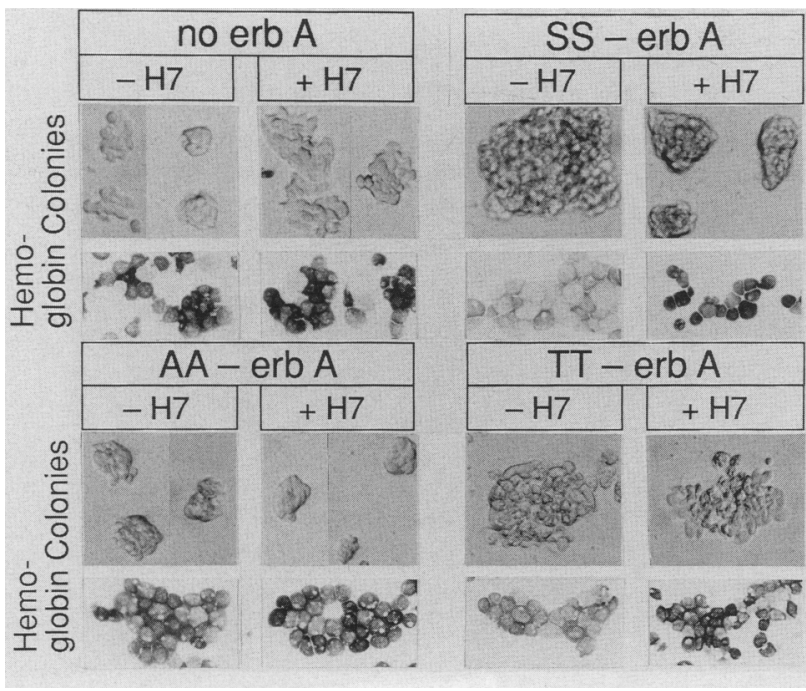

Figure 7. H7 relieves the differentiation arrest caused by the phosphorylated SS gag/v-erbA and TT gag/v-erbA oncogene proteins. Erythroblasts containing no erbA, wild-type erbA (SSerbA) or mutant $e r b \mathrm{~A}$ (AA- and TT-erbA; same clones used as in Fig. 4 and Table 1) were either seeded in semisolid medium or grown in mass cultures at $42^{\circ} \mathrm{C}$ for 3 days in the presence $(+\mathrm{H} 7)$ or absence $(-\mathrm{H} 7)$ of $15 \mathrm{~mm} \mathrm{H} 7$. Photographs of typical colonies obtained in semisolid medium are shown in the upper portions (colonies), whereas cytospin preparations of the respective mass cultures photographed under blue light after staining with neutral benzidine plus histological dyes (see legend to Fig. 3) are shown in the lower portions (hemoglobin).

gene transcription by the gag/v-erbA oncogene protein is effectively modulated by phosphorylation of Ser-16/17.

\section{Discussion}

Possible pathways involved in regulating phosphorylation and biological activity of the $\mathrm{gag} / \mathrm{v}$ erb $A$ protein

In this study three lines of evidence have been presented that suggest phosphorylation at Ser-16/17 is involved in the regulation of v-erbA oncoprotein function. First, mutation of Ser-16/17 to alanine residues, which prevents phosphorylation at this site, resulted in an essentially inactive $g a g / \mathrm{v}-e r b \mathrm{~A}$ protein. Second, an analogous substitution to threonine residues, which preserves a basal phosphorylation level but fails to maintain the ability of the $g a g / v-e r b A$ protein to respond to either PKA or PKC activators by enhanced phosphorylation, yielded a partially active $g a g / v-e r b A$ protein. Third, the function of the $g a g / v-e r b A$ protein can be severely affected in vivo by preventing its phosphorylation, using a rather nonspecific inhibitor of serine protein kinases (H7) at concentrations low enough to prevent toxic effects. This latter result, together with the fact that an antibody raised against a synthetic peptide containing amino acid residues 5-28 of wild-type $g a g / v-e r b A$ protein bound to both AA-gag/v-erbA and SS-gag/v-erbA proteins with the same affinity (C. Glineur et al., un- publ.) make it unlikely that conformational changes unrelated to phosphorylation are responsible for the loss of function of the AA-gag/v-erbA protein.

The identity of the proximal protein kinase responsible to basal phosphorylation of gag/v-erbA protein in erythroblasts remains unknown. Two lines of evidence suggest that it is unlikely to be PKC. First, immunoaffinity-purified $g a g / \mathrm{v}$-erbA protein appears to be a poor substrate for purified PKC in vitro (Goldberg et al. 1988). Second, down-regulation of intracellular PKC in AEVtransformed erythroblasts by long-term treatment with PMA failed to affect the basal phosphorylation of the $g a g / \mathrm{v} \cdot e r b \mathrm{~A}$ protein, although it completely suppressed the enhanced phosphorylation by PKC activators (Y. Goldberg and J. Ghysdael, unpubl.). In contrast, the catalytic subunit of PKA efficiently phosphorylated $g a g / \mathrm{v}$ erbA protein at Ser-16/17 in vitro (or a synthetic peptide encompassing Ser-16/17; Goldberg et al. 1988). However, in parallel assays, PKA proved unable to phosphorylate the TT-gag/v-erbA protein in vitro /C. Glineur et al., unpubl.), yet this protein is phosphorylated in both erythroblasts and fibroblasts, although at a lower level in its v-erbA-encoded domain than the wild-type protein (Fig. 2). If the same kinase is responsible for the basal phosphorylation of both wild-type and TT-gag/v-erbA proteins in vivo, it would therefore appear that PKA is also not involved in the basal phosphorylation of $g a g / v$ erbA protein in cells. Because mutation of Ser-16/17 to threonine suppresses the enhanced phosphorylation of the gag/v-erbA protein following treatment with forskolin, our data are consistent with the idea that PKA is directly responsible for the enhanced phosphorylation of wild-type gag/v-erbA protein observed in vivo following treatments that result in an increase in the intracellular concentration of cAMP.

The TT-gag/v-erbA protein shows a weaker biological activity in v-erbB or v-sea-transformed erythroblasts as compared to the wild-type SS-gag/v-erbA protein, both in terms of its effects on the differentiation phenotype of transformed cells and on their growth medium require-

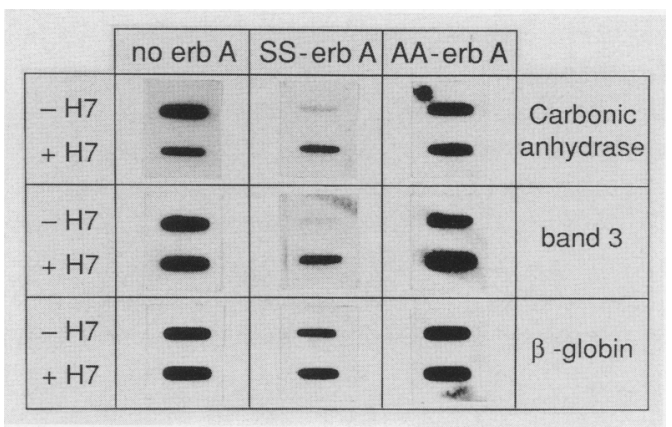

Figure 8. H7 relieves suppression of erythrocyte gene expression. Erythroblasts containing no erbA, SS gag/v-erbA, or AA gag/v-erbA (AA-erbA; same clones as in Fig. 5) were grown in $\mathrm{pH} 7.2$ medium at $42^{\circ} \mathrm{C}$ for 2 days in the presence $(+\mathrm{H} 7)$ or absence $(-\mathrm{H} 7)$ of $15 \mu \mathrm{M} \mathrm{H7}$, and expression of CA II-, band 3-, or $\beta$-globin-specific mRNA was analyzed by slot blot hybridization, as described in the legend to Fig. 5. 
ments (Fig. 3; Table 1). Whether these properties are a result of its lower stoichiometric phosphorylation under basal conditions or to its inability to respond to external signals by enhanced phosphorylation involving the PKA or PKC pathways cannot be rigorously determined on the basis of available experimental data. Trials to directly demonstrate an effect of PKA and PKC activators (e.g., forskolin and phorbol esters, respectively) on differentiation of $g a g / \mathrm{v}$-erbA-containing erythroblasts were hampered by toxic side effects of these drugs (as evidenced using ts v-sea erythroblasts) although the observed effects-a somewhat stronger differentiation arrest caused by forskolin and an induction of differentiation by phorboldibutyrate (which, when applied for 48 $\mathrm{hr}$, probably caused down-regulation of $\mathrm{PKCl}$-are in agreement with the idea that the PKA and/or PKC pathways might be involved in some way.

How does phosphorylation affect erb $A$ oncoprotein function?

Several lines of evidence indicate that lack of phosphorylation of the $g a g / \mathrm{v}-e r b \mathrm{~A}$ protein does not render the protein completely nonfunctional. First, the AA-gag/verbA protein retains its nuclear localization in transformed cells and its ability to bind in vitro either nonspecific DNA (C. Glineur et al., unpubl.) or a palindromic $\mathrm{T}_{3} \mathrm{RE}$ (Fig. 2B). Second, the AA gag/v-erbA protein, like the wild-type protein (Damm et al. 1989), is able to trans-repress a construct containing a $\mathrm{T}_{3} \mathrm{RE}$ linked to the herpes simplex virus thymidine kinase promoter in transient transfection assays (C. Glineur et al., unpubl.). Further support for the idea that regulation of $\mathrm{v}$-erbA protein function by phosphorylation may modulate its activity rather than simply turn it on or off stems from observations using c-erbA $\alpha$-expressing retroviruses. We have described elsewhere (Zenke et al. 1990) that the c-erbA $\alpha$ protein fused to viral gag sequences as in $\mathrm{v}$-erbA arrests differentiation, as well as erythrocyte gene expression in the absence of $T_{3}$, but induces (abnormal) differentiation and up-regulation of erythrocyte gene transcription in the presence of hormone. Preliminary experiments testing the effect of $\mathrm{H} 7$ on cells expressing this gag/c-erbA $\alpha$ protein suggested that phosphorylation regulates its repressor function in the absence of hormone but not its function as an activator of gene expression in response to $\mathrm{T}_{3}$. We are currently testing this hypothesis by constructing the homologous phosphorylation mutant in gag/c-erbA $\alpha$ and c-erbA $\alpha$.

The gag/v-erbA protein has recently been shown to act as a constitutive repressor of model $T_{3} R E$ in transient transfection assays (Damm et al. 1989; Sap et al. 1989). Because this property requires integrity of the DNA-binding domain of $g a g / v-e r b A$ protein, it has been proposed that competition occurs at the level of the response element by interfering with the binding of thyroid hormone receptors (Damm et al. 1989). The fact that phosphorylation of gag/v-erbA protein at Ser-16/17 is required for full biological activity in transformed erythroblasts and yet does not affect its DNA-binding ability in vitro indicates that the mode of action of $\mathrm{v}$ erbA might be more complex than anticipated previously. Phosphorylation of Ser-16/17 would appear to be required for the activity of the gag/v-erbA protein on a subset of its responsive elements, some of which would regulate the activity of genes essential to erythroid differentiation. $\mathrm{T}_{3} \mathrm{RE}$-like elements are present upstream of the CA II gene promoter region (C. Disela, H. Beug, and M. Zenke, in prep.). If these elements proved able to mediate $\mathrm{T} 3$-dependent transcriptional regulation by the c-erbA protein, the CA II gene would represent a likely direct target for repression by the $g a g / \mathrm{v}$-erbA protein.

In this context, phosphorylation of Ser-16/17 could contribute to the interaction of $g a g / v-e r b A$ protein either with other factors to stabilize its binding to these elements or with specific transcriptional activators to neutralize their trans-activating function.

\section{Implications for transcriptional regulation in other systems}

Several other members of the steroid/thyroid hormone receptor superfamily have been shown to be phosphoproteins (Dougherty et al. 1984; Logeat et al. 1985; Housley et al. 1985; Migliaccio et al. 1986; Sullivan et al. 1988), but the significance of these phosphorylation events on receptor function has not been established. The results presented here provide definitive evidence that phosphorylation can modulate the function of the oncogenic version of at least one member of the steroid/ thyroid hormone receptor superfamily. Because the phosphorylation site homologous to Ser-16/17 of $\mathrm{gag} / \mathrm{v}$ erb $\mathrm{A}$ protein is conserved and phosphorylated in the thyroid hormone receptor encoded by the chicken cerbA $\alpha$ proto-oncogene (Ser-28/29; Goldberg et al. 1988), phosphorylation at this site is likely to play a role in regulating the function of the c-erbA $\alpha$-encoded thyroid receptor as well. Because phosphorylation sites homologous to Ser-28/29 do not exist in the various mammalian thyroid hormone receptors sequenced to date /Weinberger et al. 1986; Thompson et al. 1987; Benbrook and Pfahl 1987; Izumo and Madhavi 1988; Lazar et al. 1988; Mitsuhashi et al. 1988; Nakai et al. 1988) nor in the avian c-erbA $\beta$ receptor (Forrest et al. 1990), it is unlikely that the function of these receptors is regulated in a similar fashion. This is not surprising, given the lack of identity between the amino-terminal domains of the different members of the $\mathrm{T} 3$ receptor family. The amino-terminal domain of the estrogen and progesterone receptors appears to be involved in cell-specific regulation of a subset of responsive genes (Kumar et al. 1987; Tora et al. 1988a,b). The heterogeneity of the amino-terminal domains of the various members of the thyroid hormone receptor family may be one of the components contributing to target gene specificity.

There is increasing evidence that gene expression is regulated by phosphorylation of transcription factors. Activation of PKC and cAMP-mediated pathways is known to regulate transcriptional events (Hashimoto et 
al. 1984; Comb et al. 1986; Montminy et al. 1986; Chiu et al. 1987), and several transcription factors involved in these responses have been shown to be phosphoproteins (Barber and Verma 1987; Müller et al. 1987; Gonzalez and Montminy 1987). In the case of cAMP-responsive element nuclear binding protein (CREB) - the $43-\mathrm{kD}$ protein that mediates the transcriptional response of at least some genes to cAMP (Montminy and Bilezikjian 1987)-phosphorylation by PKA has recently been shown to be required for transcriptional activity (Gonzalez and Montminy 1989|. Our results suggest that phosphorylation plays a critical role in the activity of the $g a g / v$-erbA protein as a transcriptional repressor of some of its target genes in erythroid cells. Because these results cannot easily be obtained in transient expression assays due to our limited understanding of direct target sequences for the $g a g / v-e r b A$ protein in these cells, our alternative approach of using stably integrated normal and mutated transcriptional regulators that act on target genes in their native configuration should be considered as a complementary way in helping to understand the functional regulation of transcription factors.

\section{Materials and methods}

Oligonucleotide site-directed mutagenesis of $v$-erb $A$ phosphorylation sites and construction of recombinant retroviruses

A BamHI fragment of pCGl (Jansson et al. 1987), encompassing all of v-erbA and a portion of v-erbB, was subcloned into the BamHI site of M13mp18 RF DNA. Substitution of Ser-16/17 to threonine or alanine was performed by using the oligonucleotide 5'-C CAA ACA TTG GGT GGT CTT TCT TTT G-3' and 5'-CAA ACA TTG GGC GGC CTT TCT TTT-3', respectively. Back mutation of the alanine residues at positions 16 and 17 to serine made use of the oligonucleotide 5'-CTT CAC CAA ACA TTG GGC GGC CTT TGT TTT GTG-3'.

Mutagenesis was performed by using the Amersham system, based on the method of Taylor et al. (1985). Single-stranded DNA from individual plaques was analyzed for the presence of the expected mutations by the dideoxy sequencing method. The mutagenized v-erbA genes were recovered from $\mathrm{M} 13 \mathrm{mp} 18$ RF by digestion with $X$ hoI and $A p a I$ and subcloned at the XhoI-ApaI of cloned ts $167 \mathrm{AEV}$ or erbA/ts sea proviruses (Knight et al. 1988).

Plasmids corresponding to these constructs were cotransfected together with a plasmid containing a biologically active RAV-1 provirus in chicken embryo fibroblasts by calcium phosphate coprecipitation, followed by selection with 250 $\mu \mathrm{g} / \mathrm{ml}$ neomycin (G418; GIBCO).

\section{Electrophoretic mobility-shift assays}

COS cells were transfected with the SV40 promoter-based expression plasmid pKCR3 (Breathnach and Harris 1983), encoding either SS-gag/v-erbA or AA-gag/v-erbA or pKCR3 alone as control. Two days after transfection, cells were washed three times in phosphatase-buffered saline (PBS) and $10^{7}$ cells were lysed in $200 \mu \mathrm{l}$ of $10 \mathrm{~mm}$ HEPES (pH 7.4), $1 \mathrm{~mm}$ dithiothreitol (DTT), 0.1\% Triton X-100 (wt/vol), l mM EDTA, $400 \mathrm{~mm} \mathrm{NaCl}$, $1 \%$ aprotinin, $100 \mu \mathrm{g} / \mathrm{ml}$ phenyl methylsulfonylfluoride (PMSF), and $10 \mu \mathrm{g} / \mathrm{ml}$ leupeptin (all from Sigma). Lysates were centrifuged at $100,000 \mathrm{~g}$ for $20 \mathrm{~min}$, and supernatants were col- lected. For DNA-binding reactions, $4 \mu \mathrm{l}$ of whole-cell lysates was incubated at $0^{\circ} \mathrm{C}$ in a final volume of $16 \mu$ l containing 10 mM HEPES (pH 7.4), $100 \mathrm{~mm} \mathrm{NaCl}, i .25 \mathrm{~mm}$ Na-phosphate, $0.175 \mathrm{~mm}$ EDTA, $0.075 \mathrm{mM}$ EGTA, $1 \mathrm{mM}$ DTT, $5 \mathrm{mM} \mathrm{MgCl} 2,2$ $\mu \mathrm{g}$ of poly[d(I-C)], and $0.6 \mu \mathrm{g}$ of salmon sperm DNA. After 20 min, 50 fmoles of an end-labeled $\mathrm{T}_{3} \mathrm{RE}$ palindromic oligonucleotide (Glass et al. 1989) were added, and incubation continued for $10 \mathrm{~min}$ on ice. Samples were loaded on a $5 \%$ polyacrylamide gel (acrylamide/bisacrylamide ratio $30: 1$ ) in $0.25 \times$ TBE $[1 \times$ TBE $=0.089 \mathrm{M}$ Tris, $0.089 \mathrm{M}$ boric acid, $2 \mathrm{mM}$ EDTA $(\mathrm{pH} 8.3)$, and electrophoresed at $140 \mathrm{~V}$ for $90 \mathrm{~min}$ at room temperature. Gels were fixed, dried, and exposed to Kodak XAR films for $60 \mathrm{~min}$.

\section{Cells and cell culture}

Chicken embryo fibroblasts were prepared from 11-day-old embryos of SPAFAS flocks maintained in Vienna or Lille. They were grown in standard growth medium [consisting of modified Dulbecco's modified Eagle medium (DMEM) plus $8 \%$ fetal calf serum, $2 \%$ chicken serum, and $10 \mathrm{~mm}$ HEPES (pH 7.3)]. Transformed erythroblasts were grown in CFU-E medium without anemic serum (Radke et al. 1982), unless otherwise stated.

\section{Generation of transformed erythroblast clones}

Erythroblast clones transformed by the recombinant viruses illustrated in Figure 1 were generated by infecting bone marrow cells with the respective viruses (by cocultivation of bone marrow cells with virus-producing fibroblasts for 2 days; Beug et al. 1986) and seeding them in either standard methocel (Beug and Hayman 1984) supplemented with $5 \%$ chicken serum and $1 \%$ dimethyl sulfoxide (DMSO) or, in later experiments, CFU-E-methocel (Fuhrmann et al. 1989), which contained the medium additions and erythroid hormones of differentiation medium (Zenke et al. 1988). This was necessary because some of the constructs yielded insufficient numbers of transformed colonies in standard methocel (Beug and Hayman 1984). Erythroblast clones exhibiting a long in vitro lifespan, as well as a high capacity to differentiate terminally under suitable conditions (i.e., at pH 8.1 in case of active v-erbA-containing constructs; Zenke et al. 1988), were selected as described (Knight et al. 1988; Zenke et al. 1988).

\section{Induction of differentiation transformed erythroblast clones}

For induction of differentiation in semisolid medium, $\mathrm{pH} 7.2$ methocel was supplemented with erythropoietin $12 \%$ high titer anemic serum) and REV factor at optimum concentration (Kowenz et al. 1987; Zenke et al. 1988). Then, $3 \times 10^{4}$ to $5 \times 10^{4}$ cells from transformed erythroblast clones were mixed with 0.6 $\mathrm{ml}$ of the above methocel mixture. After $3-4$ days at $42^{\circ} \mathrm{C}$ and $5 \% \mathrm{CO}_{2}$, colonies were either photographed or isolated with fine capillaries and spread on slides by using a stream of $\mathrm{CO}_{2}$ gas emerging from a Pasteur pipette at $0.5-1$ atm.

For differentiation induction in mass cultures, cells were purified by centrifugation through Percoll /density $1.070 \mathrm{~g} / \mathrm{cm}^{3}$; Schmidt et al. 1986), and seeded at $1 \times 10^{6}$ to $1.5 \times 10^{6}$ cells/ $\mathrm{ml}$ into either differentiation medium (AA-erbA) or $\mathrm{pH} 7.2 \mathrm{me}-$ dium and $\mathrm{pH} 8.1$ medium (SS-erbA, $\mathrm{SS}^{*}$-erbA), or both (TTerbA, AA-erbA), depending on the respective cell behavior elucidated in pilot experiments (Zenke et al. 1988). Media were supplemented with $1-2 \%$ high-titer anemic sera, REV factor at optimum concentration (Kowenz et al. 1987), and insulin (Zenke et al. 1988). For treatment with the protein kinase inhibitor $\mathrm{H} 7$ (Seikagaku, Gainesville, FL), the drug was dissolved 
in sterile PBS ( $10 \mathrm{~mm}$ ) and added to a final concentration of 15 $\mu \mathrm{M}$. To account for possible uptake or decay of $\mathrm{H} 7$, the addition of $10 \mu \mathrm{M} \mathrm{H} 7$ was repeated daily. After 2 days (RNA) or 3-4 days (proteins, differentiation markers) at $42^{\circ} \mathrm{C}$, cells were harvested by centrifugation and centrifugation through Percoll 11.070 $\mathrm{g} / \mathrm{cm}^{3}$ ) and Ficoll (always combining the Percoll pellet with the Ficoll interphase; Zenke et al. 1988) and were used for differentiation marker analysis, as well as immunoprecipitation and RNA extraction (see below).

\section{Analysis of erythroid differentiation markers}

Hemoglobin content of individual clones was analyzed by acid benzidine staining as described earlier (Damm et al. 1987). Stages of erythroid differentiation (erythroblasts, early reticulocytes, late reticulocytes, and erythrocytes) were analyzed by cytocentrifugation and staining with neutral benzidine plus histological dyes (Beug et al. 1982; Zenke et al. 1988). Note that the acid benzidine technique is much more sensitive than the neutral benzidine staining method, because cells heavily positive with the former method (TT-erbA; Fig. 3D) are still essentially negative with the other method (Beug et al. 1982; Zenke et al. 1990).

Cell-surface antigens were analyzed by indirect immunofluorescence as described earlier (Beug and Hayman 1984), using antisera to immature (antierythroblast serum; Beug et al. 1979) and mature erythroid cells (antierythrocyte serum; Beug et al. 1979).

\section{Cell proliferation analysis}

Erythroblasts from exponentially growing cultures of freshly thawed cells (cells approaching senescence are unsuitable for this assay) were seeded at $1 \times 10^{6} \mathrm{cells} / \mathrm{ml}$ into either standard growth medium or CFU-E medium. After daily counting in a Coulter Counter, cells were readjusted to $1 \times 10^{6}$ cells $/ \mathrm{ml}$ by using the respective media. Cumulative cell numbers were calculated, accounting for feeding with fresh medium and cell losses by counting and plotted semilogarithmically against time in culture to allow determination of doubling times.

\section{Cell labeling and immunoprecipitation procedures}

Detection of erythrocyte proteins (hemoglobin, band 3) by $\left.{ }^{35} \mathrm{~S}\right]$ methionine labeling and immunoprecipitation analysis was performed as described earlier (Beug et al. 1981; Zenke et al. 1988; Knight et al. 1989).

For [ $\left.{ }^{32} \mathrm{P}\right]$ orthophosphate labeling, cells were incubated for $2 \mathrm{hr}$ in phosphate-free MEM (GIBCO), supplemented with $3 \%$ dialyzed fetal calf serum and incubated in the same medium with $1 \mathrm{mCi} / \mathrm{ml}$ of ${ }^{32} \mathrm{P}$ ]orthophosphate for $4 \mathrm{hr}$. At the end of the labeling period, cells were rinsed in ice-cold PBS and lysed in 50 mM Tris- $\mathrm{HCl}(\mathrm{pH} 7.4), 1 \%$ Triton $\mathrm{X}-100,0.5 \%$ sodium deoxycholate, $0.1 \%$ sodium dodecylsulfate, $50 \mathrm{mM} \mathrm{NaCl}, 10 \mathrm{~mm}$ $\mathrm{NaF}, 40 \mathrm{~mm}$ p-nitrophenylphosphate, $1 \%$ aprotinin, $0.1 \mathrm{mg} / \mathrm{ml}$ PMSF, and $1 \mu \mathrm{g} / \mathrm{ml}$ leupeptin (all from Sigma). For L-[ $\left.{ }^{35} \mathrm{~S}\right] \mathrm{methi}-$ onine labeling in controls, cells were rinsed with methioninefree MEM (GIBCO), supplemented with $5 \%$ dialyzed fetal calf serum, and incubated in the same medium with L- $\left.{ }^{35} S\right]$ methionine at $250 \mu \mathrm{Ci} / \mathrm{ml}$ for $60 \mathrm{~min}$ and lysed as above. The lysates were centrifuged at $100,000 \mathrm{~g}$ for $60 \mathrm{~min}$ and immune precipitations were carried out using either normal rabbit sera or an erbA-specific antisera followed by cleavage with protease $\mathrm{p} 15$, as described previously (Goldberg et al. 1988). Immune precipitates were analyzed on $10 \%$ polyacrylamide slab gels in the presence of $0.1 \%$ SDS (SDS-PAGE). Gels were fixed in meth- anol/water/acetic acid $(5: 5: 1)$, dried, and processed for either autoradiography or fluorography.

\section{RNA preparation and blot hybridization}

Total RNA was prepared by using the guanidinium thiocyanate $\mathrm{CsCl}$ step gradient procedure (Glisin et al. 1974), with a modification as described before (Zenke et al. 1988). To obtain cytoplasmic RNA, cells were lysed with $0.5 \%$ NP-40 in $25 \mathrm{~mm}$ Tris- $\mathrm{HCl}(\mathrm{pH} 7.5), 5 \mathrm{mM} \mathrm{NaCl}$, and $1 \mathrm{mM} \mathrm{MgCl}_{2}$ in the presence of $5 \mathrm{~mm}$ Vanadyl-ribonucleoside-complex $(\mathrm{BRL})$ for $10 \mathrm{~min}$ on ice. Following centrifugation $\left(10 \mathrm{sec}, 15,600 \mathrm{~g}, 4^{\circ} \mathrm{C}\right)$, the cytoplasmic supernatant was digested extensively with proteinase $\mathrm{K}$ (Merck, $5 \mathrm{mg} / \mathrm{ml}, 2 \mathrm{hr}, 37^{\circ} \mathrm{C}$ ) in the presence of $40 \mathrm{mM}$ EDTA, $1 \% \mathrm{SDS}$, and $150 \mathrm{~mm} \mathrm{NaCl}$. The RNA obtained after phenolchloroform extraction and ethanol precipitation was transferred to GeneScreen membranes (NEN) by slot blotting. For this, $5 \mu \mathrm{g}$ of RNA was denatured in $50 \%$ (vol/vol) formamide and $0.2 \mathrm{~m}$ formaldehyde $\left(10 \mathrm{~min}\right.$ at $\left.60^{\circ} \mathrm{C}\right)$, chilled on ice, diluted 10 -fold with $20 \times$ SCC, and transferred onto the membrane in a Millipore slot blotting apparatus. Hybridization with radiolabeled probes was performed as described previously (Zenke et al. 1988).

\section{Immunofluorescence analysis}

Chicken embryo fibroblasts infected with wild-type or mutant AEVs were fixed in $3.8 \%$ formaldehyde in PBS (freshly prepared from paraformaldehyde) for $1 \mathrm{hr}$ at room temperature. Cells were permeabilized with $1 \%$ Triton $\mathrm{X}-100$ followed by a treatment with methanol at $-20^{\circ} \mathrm{C}$ for $5 \mathrm{~min}$. Fixed cells were preincubated with a $5 \%$ solution (wt/vol) of powdered milk in PBS for 30 min at room temperature and then incubated with a $1: 200$ dilution of an erbA-specific rabbit antiserum (Goldberg et al. 1988) or a nonimmune rabbit control serum for $60 \mathrm{~min}$ at room temperature. After four washes in PBS, cells were incubated with a $1: 400$ dilution of fluoroscein isothyocynate-conjugated swine anti-rabbit IgG antiserum (Biosis). After washing and mounting in Elvanol, immunofluorescence was examined under a Zeiss epifluorescence microscope.

\section{Acknowledgments}

We thank Drs. B. Vennström and J. Sap for helpful discussions, Dr. P. Boucher for critical reading of the manuscript, M. Bailly, G. Doederlein, G. Stengl, and G. Woznycka for expert technical assistance, and N. Devassine and M.C. Bouchez for secretarial assistance. This work was supported by funds from the Institut National de la Santé et de la Recherche Médicale (INSERM), Centre National de La Recherche Scientifique (CNRS), Institut Pasteur de Lille, and Association pour la Recherche sur le Cancer (ARC).

The publication costs of this article were defrayed in part by payment of page charges. This article must therefore be hereby marked "advertisement" in accordance with 18 USC section 1734 solely to indicate this fact.

\section{References}

Barber, J.R. and I.M. Verma. 1987. Modification of Fos protein: Phosphorylation of $c$-fos but not $v$-fos, is stimulated by 12 tetradecanoyl-phorbol-13-acetate and serum. Mol. Cell. Biol. 7: 2201-2211.

Benbrook, D. and M. Pfahl. 1987. A novel thyroid hormone receptor encoded by a cDNA clone from a human testis library. Science 238: 788-791. 
Beug, H. and M.J. Hayman. 1984. Temperature-sensitive mutants of avian erythroblastosis vinus: Surface expression of the erbB product correlates with transformation. Cell 36: $963-972$.

Beug, H., A. Von Kirchbach, G. Döderlein, J.F. Conscience, and T. Graf. 1979. Chicken hematopoietic cells transformed by seven strains of defective avian leukemia viruses display three distinct phenotypes of differentiation. Cell 18: $375-$ 390.

Beug, H., T. Graf, and M.J. Hayman. 1981. Production and characterization of antisera specific for the erb-portion of $\mathrm{p} 75$, the presumptive transforming protein of avian erythroblastosis vinus. Virology 111: 201-210.

Beug, H., G. Döderlein, C. Freudenstein, and T. Graf. 1982a. Erythroblast cell lines transformed by temperature-sensitive mutants of avian erythroblastosis vinus: A model system to study erythroid differentiation in vitro. J. Cell. Physiol. Suppl. 1: 195-207.

Beug, H., S. Palmieri, C. Freudenstein, H. Zentgraf, and T. Graf. 1982b. Hormone-dependent terminal differentiation in vitro of chicken erythroleukemia cells transformed by ts mutants of avian erythroblastosis virus. Cell 28: 907-919.

Beug, H., T. Graf, and M.J. Hayman. 1984. Production and characterization of antisera specific for the erb-portion of $\mathrm{p} 75$, the presumptive transforming protein of avian erythroblastosis virus. Virology 111: 201-210.

Beug, H., P. Kahn, G. Döderlein, M.J. Hayman, and T. Graf. 1985a. Characterization of hematopoietic cells transformed in vitro by $\mathrm{AEV}-\mathrm{H}$, and erb-containing avian erythroblastosis virus. In Modern trends in human leukemia VI (ed. R. Neth, R. Gallo, M. Greaves, and K. Jankal, vol. 29, pp. 290-297. Springer-Verlag, Berlin-Heidelberg.

Beug, H., M.J. Hayman, T. Graf, S.H. Benedict, A.M. Walbank, and P.K. Vogt. 1985b. S13, a rapidly oncogenic replicationdefective avian retrovirus. Virology 145: 141-153.

Beug, H., M.J. Hayman, M.B. Raines, H.J. Kung, and B. Vennström. 1986. RAV-1 induced erythroleukemic cells exhibit a weakly transformed phenotype in vitro and release c-erb B containing retroviruses unable to transform fibroblasts. $I$. Virol. 57: 1127-1138

Breathnach, R. and B.A. Harris. 1983. Plasmid for the cloning and expression of full-length double stranded cDNAs under the control of the SV40 early and late gene promoter. $\mathrm{Nu}$ cleic Acids Res. 11: 7119-7136.

Chiu, R., M. Imagawa, R. Imbra, J.R. Bockoven, and M. Karin. 1987. Multiple cis- and trans-acting elements mediate the transcriptional response to phorbol esters. Nature 329: 648651.

Comb, M., N.C. Birnberg, A. Seascholtz, E. Herbert, and H.M. Goodman. 1986. A cyclic-AMP and phorbol ester inducible DNA-element. Nature 323: 353-356.

Damm, K., C.C. Thomson, and R.M. Evans. 1989. Protein encoded by $v$-erbA functions as a thyroid hormone receptor antagonist. Nature 339: 593-597.

Damm, K., H. Beug, T. Graf, and B. Vennström. 1987. A single point mutation in erbA restores the erythroid transforming potential of a mutant avian erythroblastosis virus (AEV) defective in both $e r b A$ and $e r b B$ oncogenes. $E M B O ~ \%$. 6: 375 382.

de The, H., A. Marchio, P. Tiollais, and A. Dejean. 1987. A novel steroid thyroid hormone receptor-related gene inappropriately expressed in human hepatocellular carcinoma. Nature 330: 667-670.

Dougherty, J.J., R.K. Puri, and D.O. Toft. 1984. Polypeptide components of two $8 \mathrm{~S}$ forms of chicken oviduct progesterone receptor. J. Biol. Chem. 259: 8004-8009.
Evans, R.M. 1988. The steroid and thyroid hormone receptor superfamily. Science 240: 889-895.

Forrest, D., M. Sjöberg, and B. Vennström. 1990. Contrasting developmental and tissue-specific expression of $\alpha$ and $\beta$ thyroid hormone receptor genes. EMBO /. 9: 1519-1528.

Frykberg, L., S. Palmieri, H. Beug, T. Graf, M. Hayman, and B. Vennström. 1983. Transforming capacities of avian erythroblastosis virus mutants deleted in the erbA or erbB oncogenes. Cell 32: 227-238.

Fuhrmann, U., B. Vennström, and H. Beug. 1989. The myeloid cell specific mutated growth factor receptor v-fms transforms avian erythroid but not myeloid cells. Genes Dev. 3: $2072-2082$.

Fung, Y.K.T., W.G. Lewis, H.J. Kung, and L.B. Crittenden. 1983. Activation of the cellular oncogene $c-e r b B$ by LTR insertion: Molecular basis for induction of Cell 33: 357-368.

Giguere, V., E.S. Ong, P. Segui, and R.M. Evans. 1987. Identification of a receptor for the morphogen retinoic acid. Nature 330: 624-629.

Glass, C.K., S.M. Lipkin, Devary, and M.G. Rosenfeld. 1989. Positive and negative regulation of gene transcription by retinoic acid-thyroid hormone receptor heterodimer. Cell 59: 697-708.

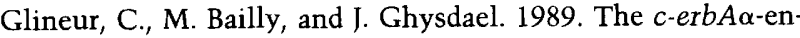
coded thyroid hormone receptor is phosphorylated in its amino terminal domain by casein kinase II. Oncogene 4: $1247-1254$.

Glisin, V., R. Crkvenjakov, and C. Byus. 1974. Ribonucleic acid isolated by celsium chloride centrifugation. Biochemistry 13: $2633-2637$

Goldberg, Y., C. Glineur, J.C. Gesquiere, A. Ricouart, J. Sap, B. Vennström, and J. Ghysdael. 1988. Activation of protein kinase $C$ or c-AMP-dependent protein kinase increases phosphorylation of the c-erbA-encoded thyroid hormone receptor and of the v-erbA-encoded protein. EMBO J. 7:24252433.

Gonzalez, G.A. and M.R. Montminy. 1989. Cyclic AMP stimulates somatostatin gene transcription by phosphorylation of CREB at serine 133. Cell 59: 675-680.

Graf, T., N. Ade, and H. Beug. 1978. Temperature-sensitive mutant of avian erythroblastosis virus suggests a block of differentiation as mechanism of leukoemogenesis. Nature 275: 496-501

Graupner, G., K.N. Wills, M. Tzukevman, X. Zhang, and M. Pahl. 1989. Dual regulatory role for thyroid hormone receptors allows control of retinoic acid receptor activity. $\mathrm{Na}$ ture 340: 563-656.

Green, S. and P. Chambon. 1986. A superfamily of potentially oncogenic hormone receptors. Nature 324: 615-617.

Greenberg, M. and E.B. Ziff. 1984. Stimulation of 3T3 cells induces transcription of the $c$-fos protooncogene. Nature 311: $433-438$.

Hashimoto, S., W. Schmid, and G. Schütz. 1984. Transcriptional activation of the rat liver tyrosine transferate gene by cAMP. Proc. Natl. Acad. Sci. 81: 6637-6641.

Hidaka, H., M. Inagaki, S. Kawamoto, and Y. Sasaki. 1984. Isoquinoline sulfonamides novel and potent inhibitors of cyclic nucleotide dependent protein kinases and protein kinase $\mathrm{C}$. Biochemistry 23: 5036-5041.

Housley, P.R., E.R. Sanchez, H.M. Westphal, M. Beato, and W.B. Pratt. 1985. The molybdate-stabilized L-cell glucocorticoid receptor isolated by affinity chromatography or with a monoclonal antibody is associated with a 90-92 kDa nonsteroid-binding phosphoprotein. J. Biol. Chem. 260: 1381013817.

Izumo, S. and V. Madhavi. 1988. Thyroid hormone receptor and 
isoforms generated by alternative splicing differentially activate myosin HC gene transcription. Nature 334: 539-542.

Jansson, M., H. Beug, C. Gray, T. Graf, and B. Vennström. 1987. Defective v-erbB genes can be complemented by v-erbA in erythroblast and fibroblast transformation. Oncogene 1: $167-173$.

Kahn, P., L. Frykberg, T. Graf, B. Vennström, and H. Beug. 1986a. Cooperativity between $v$-erbA and $V$-src-related oncogenes in erythroid cell transformation. In XII. Symposium for comparative research on leukemia and related diseases (ed. F. Deinhard), pp. . Springer-Verlag, Heidelberg.

Kahn, P., L. Frykberg, C. Brady, I. Stanley, H. Beug, B. Vennström, and T. Graf. 1986b. v-erbA cooperates with sarcoma oncogenes in leukemia cell transformation. Cell 45: 349356.

Kawamoto, S. and H. Hidaka. 1984. 1-(5-Isoquinoline sulfonyl)2-methylpiperazine $(\mathrm{H} 7)$ is a selective inhibitor of protein kinase $\mathrm{C}$ in rabbit platelets. Biochem. Biophys. Res. Commun. 125: 258-264.

Knight, J., M. Zenke, C. Disela, E. Kowenz, P. Vogt, D. Engel, M.J. Hayman, and H. Beug. 1988. Temperature-sensitive v-sea transformed erythroblasts: A model system to study gene expression during erythroid differentiation. Genes Dev. 2: $247-258$.

Koenig, R., R.L. Warne, G.A. Brent, J.W. Harney, P.R. Larsen, and D.D. Moore. 1988. Isolation of a cDNA clone encoding a biological active thyroid hormone receptor. Proc. Natl. Acad. Sci. 85: 5031-5035.

Kowenz, E., A. Leutz, G. Döderlein, T. Graf, and H. Beug. 1987. Ts oncogene transformed erythroleukemia cells: A novel test system to purify and characterize avian erythroid growth factors. In Modern trends in human leukemia VII (ed. R. Neth, R. Gallo, M. Greaves, and H. Kabisch), vol. 31, pp. 199-209. Springer-Verlag, Berlin.

Kumar, V., S. Green, G. Stack, M. Berry, J.R. Jin, and P. Chambon. 1987. Functional domains of the human estrogen receptor. Cell 51: 941-951.

Lamph, W.W., P. Wamsley, P. Sassone-Corsi, and I.M. Verma. 1988. Induction of proto-oncogene Jun/AP1 by serum and TPA. Nature 334: 629-631.

Lazar, M.A., R.A. Hodin, D.S. Darling, and W.W. Chin. 1988. Identification of a rat $c$-erbA $\alpha$-related protein which binds DNA but does not bind thyroid hormone. Mol. Endocrinol. 2: 893-901.

Logeat, F., M. Le Cunff, R. Pamphile, and E. Milgrom, 1985. The nuclear-bound form of the progesterone receptor is generated through a hormone-dependent phosphorylation. Biochem. Biophys. Res. Commun. 131: 421-427.

Migliaccio, A., A. Rotondi, and F. Auricchio. 1986. Estradiol receptor: phosphorylation on tyrosine in uterus and interaction with anti-phosphotyrosine antibody. EMBO /. 5: 28672872.

Mitsuhashi, T., G.E. Tennyson, and V.M. Nikodem. 1988. Alternative splicing generates messages encoding rat $c$-erbA proteins that do not bind thyroid hormone. Proc. Natl. Acad. Sci. 85: 5804-5808.

Montminy, M.R. and L.M. Bilezikjian. 1987. Binding of a nuclear protein to the cyclic AMP responsive elements of the somatostatin gene. Nature 328: 175-178.

Montminy, M., K. Sevarino, J. Wagner, G. Mandel, and R.H. Goodman. 1986. Identification of a cyclic-AMP-responsive element within the rat somatostatin gene. Proc. Natl. Acad. Sci. 83: 6682-6686.

Müller, R., R. Bravo, D. Müller, C. Kurz, and M. Renz. 1987. Different types of modification in $c$-fos and its associated protein p39: Modulation of DNA binding by phosphoryla- tion. Oncogene Res. 2: 19-32.

Munoz, A., M. Zenke, U. Gehring, J. Sap, H. Beug, and B. Vennström. 1988. Characterization of the hormone binding domain of the chicken $c-e r b A /$ thyroid hormone receptor protein. $E M B O$ I. 7: 155-159.

Nakai, A., S. Seino, A. Sakurai, I. Szilak, G. Bell, and L.I. De Groot. 1988. Characterization of a thyroid hormone receptor expressed in human kidney and other times. Proc. Natl. Acad. Sci. 85: 2781-2785.

Petkovich, M., N.J. Brand, A. Krust, and P. Chambon. 1987. A human retinoic acid receptor which belongs to the family of nuclear receptors. Nature 330: 444-450.

Radke, K., H. Beug, S. Kornfeld, and T. Graf. 1982. Transformation of both erythroid and myeloid cells by E26, an avian leukemia virus that contains the myb gene. Cell 31: 643653.

Samarut, J. and L. Gazzolo. 1982. Target cells infected by avian erythroblastosis virus differentiate and become transformed. Cell 28: 921-929.

Sap, J., A. Munoz, J. Schmitt, H. Stunnenberg, and B. Vennström. 1989. Repression of transcription mediated at a thyroid hormone response element by the $v$-erbA oncogene product. Nature 340: 242-244.

Sap, J., A. Munoz, K. Damm, Y. Goldberg, J. Ghysdael, A. Leutz, H. Beug, and B. Vennström. 1986. The c-erbA protein is a high affinity receptor for thyroid hormone. Nature 324: 635-640.

Schmidt, J.A., J. Marshall, M.J. Hayman, P. Ponka, and H. Beug. 1986. Control of erythroid differentiation: Possible role of the transferrin cycle. Cell 46: 41-51.

Scotting, P., B. Vennström, M. Jansson, T. Graf, H. Beug, and M.J. Hayman. 1987. Common site of mutation in the erbB gene of avian erythroblastosis virus mutants that are temperature-sensitive for transformation. Oncogene Res. 1: 265-278.

Sealy, L., M.L. Privalsky, G. Moscovici, C. Moscovici, and J.M. Bishop. 1983. Site-specific mutagenesis of avian erythroblastosis virus: $e r b B$ is required for oncogenicity. Virology 130: $155-178$.

Sen, R. and D. Baltimore. 1986. Inducibility of K immunoglobulin enhancer-binding protein NF-K-B by a post-translational mechanism. Cell 47: 921-928.

Sullivan, W.P., B.J. Madden, D.J. McCormick, and D.O. Toft. 1988. Hormone-dependent phosphorylation of the avian progesterone receptor. J. Biol. Chem. 263: 14717-14723.

Taylor, J.W., J. Ott, and F. Eckstein. 1985. The rapid generation of oligonucleotide directed mutations at high frequency using phosphonothioate-modified DNA. Nucleic Acids Res. 13: $8764-8785$.

Thomson, C.C., C. Weinberg, R. Lebo, and R.M. Evans. 1987. Identification of a novel thyroid hormone receptor expressed in the mammalian central nervous system. Science 237: $1610-1614$.

Tora, L., H. Gronemeyer, B. Turcotte, M.P. Gaub, and P. Chambon. 1988a. The N-terminal region of the chicken progesterone receptor specifies target gene activation. Nature 333: $185-188$.

Tora, L., M.P. Gaub, S. Mader, A. Dierich, M. Bellard, and P. Chambon. 1988b. Cell specificity of a GGTCA half-palindromic oestrogen-responsive element in the chicken ovalbumin gene reporter. EMBO I. 7: 3771-3778.

Umesono, K., V. Giguere, C. Glass, M. Rosenfeld, and R. Evans. 1988. Retinoic acid and thyroid hormone induce gene expression through a common responsive element. Nature 336: $262-265$.

Weinberger, C., S.M. Hollenberg, M.G. Rosenfeld, and R.M. 


\section{Glineur et al.}

Evans. 1985. Domain structure of human glucocorticoid receptor and its relationship to the $v$-erbA oncogene products. Nature 318: 670-672.

Weinberger, C., C.C. Thompson, E.S. Ong, R. Lebo, D.J. Gruol, and R.M. Evans. 1986. The c-erbA gene encodes a thyroid hormone receptor. Nature 324: 641-646.

Zenke, M., A. Munoz, J. Sap, B. Vennström, and H. Beug. 1990. $v$-erbA oncogene activation entails the loss of hormone-dependent regulator activity of c-erbA. Cell 61: 1035-1049.

Zenke, M., P. Kahn, C. Disela, B. Vennström, A. Leutz, K. Keegan, M. Hayman, H. Choi, J.D. Engel, and H. Beug. 1988. $v$-erbA specifically suppresses transcription of the avian erythrocyte anion transporter (Band 3) gene. Cell 52: 107119. 


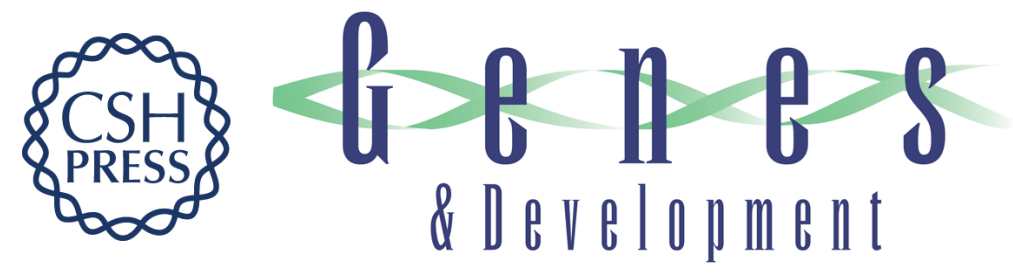

\section{Phosphorylation of the v-erbA protein is required for its function as an oncogene.}

C Glineur, M Zenke, $\mathrm{H}$ Beug, et al.

Genes Dev. 1990, 4:

Access the most recent version at doi:10.1101/gad.4.10.1663

References This article cites 71 articles, 15 of which can be accessed free at:

http://genesdev.cshlp.org/content/4/10/1663.full.html\#ref-list-1

License

Email Alerting

Service

Receive free email alerts when new articles cite this article - sign up in the box at the top right corner of the article or click here.

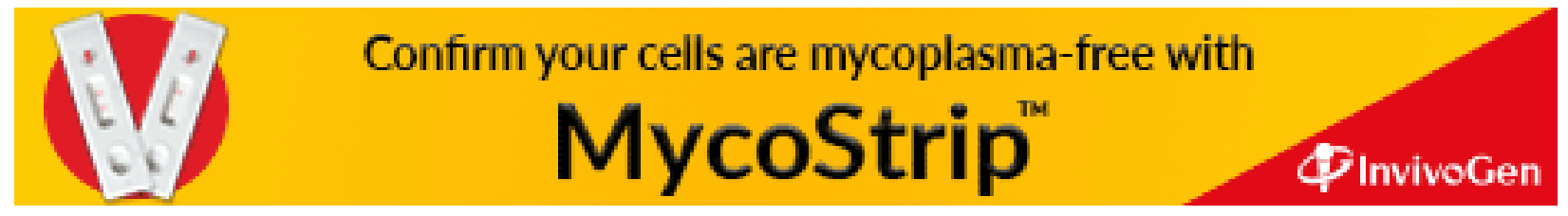

